\title{
CEPA
}

Center for Economic Policy Analysis

\section{Does Trade Promote Gender Wage Equity? Evidence from East Asia}

Günseli Berik (University of Utah),

Yana van der Meulen Rodgers (College of William and Mary), and Joseph E. Zveglich, Jr. (Asian Development Bank)

CEPA Working Paper 2002-14

August 2002

\author{
Center for Economic Policy Analysis \\ New School University \\ 80 Fifth Avenue, Fifth Floor, New York, NY 10011-8002 \\ Tel. 212.229.5901 • Fax 212.229.5903 \\ www.newschool.edu/cepa
}




\title{
Does Trade Promote Gender Wage Equity?
}

\section{Evidence from East Asia}

\author{
Günseli Berik* $^{*}$ \\ University of Utah \\ Yana van der Meulen Rodgers \\ College of William and Mary \\ Joseph E. Zveglich, Jr \\ Asian Development Bank \\ Prepared for \\ Labor and the Globalization of Production \\ Center for Economic Policy Analysis, New School University
}

June 2002

\footnotetext{
* The authors thank Theodora Galabova, Jim Gander, Andrew Mason, Will Milberg, Susan Razzaz, and Sarah Stafford for their assistance and suggestions. Seminar participants at the New School University's Center for Economic Policy Analysis, the University of Utah and the College of William and Mary's economics departments, the Levy Economics Institute of Bard College, and the World Bank provided useful comments. This work is supported by funding from the World Bank and a College of William and Mary Faculty Research Assignment. The views in this paper are those of the authors and do not necessarily reflect the views and policies of the Asian Development Bank or of the World Bank and its board of directors.
} 


\title{
Does Trade Promote Gender Wage Equity? \\ Evidence from East Asia
}

\begin{abstract}
This study explores the impact of competition from international trade on the gender wage gap in Taiwan and South Korea between 1980 and 1999. The dynamic implications of Becker's (1959) theory of discrimination lead one to expect that increased competition from international trade reduces the incentive for employers to discriminate against women. This effect should be more pronounced in concentrated sectors of the economy, where employers can use excess profits to cover the costs of discrimination. Alternatively, wage discrimination may increase with growing trade in a context of employment segregation that limits women's ability to achieve wage gains. The empirical strategy controls for differences in market structure across industries in order to isolate the effect of competition from international trade. Estimation results are not consistent with Becker's theory, as greater international competition in concentrated sectors is associated with larger wage gaps between men and women.
\end{abstract}

(JEL codes F14, F15, J31) 


\section{Introduction}

During the last several decades, industry and export mixes in Taiwan and South Korea have shifted toward higher-skill, technology-intensive products, while lower-skill, laborintensive industries have been moving abroad. At the same time, women's relative educational attainment and skill levels improved considerably. Yet some trends have differed across these two economies. Taiwan became increasingly open to trade, with a steady rise in the total trade to output ratio from a low of $48 \%$ in the early 1980 s to a high of almost $90 \%$ by the late 1990 s. Against this backdrop, Taiwan's average female-male wage ratio in manufacturing dropped fairly steadily from $66 \%$ in 1981 to $60 \%$ in 1993 . Only in the mid-1990s did the wage ratio begin a strong climb upward, reaching $67 \%$ by 1999 . In contrast, Korea's slow and steady improvement in women's relative wages-from $47 \%$ in 1980 to $58 \%$ by 1998 - was accompanied by a slight decline in trade openness. ${ }^{1}$ Industrial structure and policy also differ between the two economies, with Taiwan having a higher proportion of small firms and relatively less emphasis on selective government intervention. These divergent features in two of the most successful practitioners of the export-led growth model make Taiwan and Korea well-suited to examine the impact of international trade competition on the gender wage gap.

Increased participation in the global economy is expected to generate growing pressures on firms to engage in cost-cutting practices that may affect female employees differently than male employees, particularly if sex discrimination plays a role in firms' hiring and pay decisions. The dynamic implications of Becker's (1959) theory of discrimination lead us to expect that if discrimination is costly, then increased competition from international trade will reduce the incentive for employers to discriminate against women. This effect should be more pronounced in concentrated sectors of the economy, where employers can use excess profits to cover the 
costs of discrimination. Alternatively, wage discrimination may increase with growing trade in a context of employment segregation that limits women's ability to achieve wage gains. For example, trade competition can entail technological restructuring that contributes to women's absorption into lower paying jobs and a relative loss of power in wage bargaining situations.

Following the approaches in Borjas and Ramey (1995) and Black and Brainerd (2000), the empirical strategy controls for differences in market structure across industries in order to isolate the effect of competition from international trade. The methodology is applied separately to Taiwan and Korea, and the results are compared. To control for the effects of changes in worker productivity characteristics, estimations are performed using average residual wage gaps as well as average unadjusted wage gaps by industry. The residual wage gap - the portion of the wage gap that cannot be explained by observed productivity differences between men and women - is commonly attributed to wage discrimination against women.

This study contributes to scholarship on globalization by yielding new evidence on the impact of competition from international trade on the gender wage gap in two of the world's most trade-oriented economies. By integrating micro data on labor markets with macro data on industrial structure and trade, the study moves beyond the unsatisfactory treatment of discrimination in the labor literature as an unexplained residual. At the same time it can include controls for worker productivity characteristics that are lacking in studies that pursue an industry-level analysis of gender wage differentials. Previous research on the effect of increasing competition on wage discrimination is still inconclusive and limited in geographical coverage, leaving the impact of globalization on the gender gap an empirical puzzle. 


\section{Competition and the Gender Wage Gap: Existing Research}

According to neoclassical theory based on Gary Becker's The Economics of Discrimination (1959), long-run competition is not compatible with persistent discrimination. The existence of an equally productive but underpaid group of workers will attract profit maximizing firms that don't have discriminatory tastes against this group. Hence the expansion of demand for the group that is discriminated against will gradually eliminate the wage differential. Discrimination will persist only in the least competitive sectors. There employers and managers, who choose to indulge their taste for discrimination by avoiding to hire the lower paid workers and employing higher cost labor instead, can continue to engage in costly discrimination as long as they are making excess profits. Under increasing competition in these industries - through, for example, deregulation of the industry, entry of new firms, or competition from cheaper imports - the use of the underpaid labor is expected to grow and gradually the increase in demand will bid up the wages of this group of workers, reducing the wage gap. ${ }^{2}$

Consistent with this theoretical notion of discrimination, empirical studies operationalize discrimination as the wage differential that remains after accounting for all measured productivity differences between two groups. This differential is labeled as the "unexplained residual" wage difference. ${ }^{3}$ A fairly small number of empirical studies have examined the hypothesis that increased competition leads to less gender discrimination and an improvement in women's relative wages. Among studies of competition in domestic product markets, Black and Strahan (2001) find that by reducing rents that previously accrued to men, banking-sector deregulation leads to improvements in women's relative wages beyond what can be explained by improvements in women's skill characteristics. Also for the United States, Hellerstein, Neumark 
and Troske (1997) find evidence of wage discrimination against female employees among plants with higher levels of product market power. This finding is not evident in plants with lower levels of market power.

In the labor market, less domestic regulation can contribute to the weakening of antidiscrimination laws and their enforcement, thus generating the result that greater competition enlarges the gender wage gap. For example, Meng (1996) reports that the unexplained portion of the gender wage gap is considerably larger for the rural industrial sector in China than for the urban state sector. The author concludes that wage discrimination by gender is more problematic in the rural industrial sector because the relative lack of government involvement has strengthened traditional attitudes toward the unequal roles of men and women in the labor market. But other researchers argue that more competitive labor markets should work to women's advantage by penalizing firms that discriminate against women, whereas less competitive labor markets increase the potential for firms to engage in gender discrimination. For example, Winter-Ebmer (1995) finds that in Austria, monopsony power among firms contributes to larger gender wage gaps. ${ }^{4}$

Among studies of competition from international trade, Black and Brainerd (2000) find that in United States manufacturing industries that are both concentrated and increasingly exposed to competing imports, the residual gender wage gap narrows to a greater extent than in non-concentrated, trade impacted industries. The authors interpret this result as evidence supporting Becker's hypothesis that discrimination cannot persist in an increasingly competitive environment. The authors also find that increased trade openness in general, controlling for domestic and international competitiveness, increases the U.S. gender wage gap. Curiously, the authors attribute this latter result to the adverse effect of trade on the wages of unskilled workers 
(presumed to be predominantly female), even though regressions with residual wages already control for worker skill characteristics. A drawback of the study is its application to data from the United States, a relatively closed economy. Artecona and Cunningham (2001) apply Black and Brainerd's methodology to Mexico and obtain similar but weaker results. The authors find that the residual gender wage gap declined more in concentrated industries that were affected by trade liberalization than in non-concentrated industries, supporting the hypothesis that trade liberalization made it more expensive for firms to discriminate against women. Similar to Black and Brainerd, the authors also find that trade liberalization alone widened the gender wage gap.

In a cross-country analysis using data for 3 middle-income and 13 high-income countries, Behrman and King (1999) find some evidence that increased competitive pressure due to trade openness is associated with higher gender wage ratios. Although this result controls for the impact of competition in domestic markets, as measured by the number of firms relative to production by sector, it is not robust across sample specifications. A smaller-scale case study of women in Mexico's rural sector shows significant improvements in women's wages following Mexico's increase in trade openness (Gladwin and Thompson 1995).

By contrast, Zveglich, Rodgers, and Rodgers (1997) and Rodgers (1998) strike a cautionary note against optimism about trade openness. These studies determine how changes over time in measured skill characteristics and their market returns contribute to the evolution of the wage gap in Taiwan and Korea. They conclude that women experienced growing losses in unmeasured gender-related factors over time-losses that worked against women's relative improvements in education and experience. These unexplained losses more than offset women's measured productivity gains in Taiwan during the 1980s and early 1990s, while they partially offset women's productivity gains in Korea in the same period. While these studies do not 
explicitly relate trade competition to trends in residual gender wage gaps, they do suggest a possible rise in wage discrimination during a period of outward-oriented growth.

In sum, the empirical studies that examine the impact of increased exposure to competitive forces on the gender wage gap, often controlling for contemporaneous changes in detailed worker characteristics, have yielded results that are largely inconclusive. In addition to this group of studies, there are a smaller number of studies that have adopted the nonneoclassical perspective on the labor market and have sought to examine the relationship between trade and the gender wage gap in the context of East Asian countries.

In the non-neoclassical approach, wages are determined by not only labor quality, but also industry characteristics, which are the product of competition among firms within an industry and across industries. ${ }^{5}$ Competition is the tendency for uniform profit rates to emerge across industries under conditions of capital mobility. In contrast to the neoclassical concept, competition is not antithetical to, but encompasses, monopoly and tendencies toward industrial concentration, since concentration may facilitate mobility of capital and equalization of the profit rate. Moreover, competition involves not only rivalry and conflict among different firms within and across industries but also competition among groups of workers.

According to this approach, discrimination is not an aberration that arises when competitive conditions fail to hold. On the contrary, it is a product of competition among firms and groups of workers, each behaving in economically rational ways. In this approach, the existence of a hierarchy of jobs and the specter of joblessness are the preconditions for discrimination. In response to these employment conditions, established groups in the labor market become primary agents of discrimination. These privileged groups act collectively to secure favorable employment conditions in a self-interested manner and engage in exclusionary 
behavior. The groups' respective bargaining power, shaped by their recent social class history, will determine how successful each group will be in securing favorable employment conditions. In this approach, the agency of the established group of workers, by virtue of its greater collective power, will shape the pattern of employment segregation and the position where each group is able to locate itself in the job hierarchy.

In this tradition, feminist economists have long argued that organized action by male workers has shaped the gender-segregated structure of jobs in industrial economies and the associated lower pay for women workers (Hartmann 1979; Milkman 1990). In the context of contemporary East Asia, given the weakness of organized labor for much of this period, male workers may not have been as instrumental in shaping the gender-segregated patterns of employment. A number of studies present evidence to show that, instead, employment segregation by gender in Korea and Taiwan is produced by employer and state hiring, training, employment, and labor control policies in a context of patriarchal gender norms (Seguino 1997; Cheng and Hsiung 1994; Nam 1994). Women are excluded from higher paying, skilled occupations because they are denied access to training, or steered away by gender specific job advertisements. Their employment experience and potential for wage increases are cut short by the employer practice of the "marriage bar." Furthermore, women's wage growth is dampened by the state's promotion of home-based work and relaxation of immigration rules to expand the supply of labor. In turn, the restriction of women's employment opportunities via these policies limits women's bargaining power vis-a-vis employers, and therefore their ability to secure wage gains. The state's emphasis on suppressing collective bargaining in export industries, where women workers are concentrated, has translated into relatively more suppression of women's bargaining efforts. The state may have implemented some of these policies with the objective of 
supporting continued export competitiveness, rather than perpetuating gender inequalities; nonetheless, their effect is likely to have perpetuated gender wage inequalities. Feminist economists also argue that Taiwan and Korean firms may have sought to preserve labor peace by favoring men over women in their employment policies. Furthermore, wage discrimination against women workers in export industries may have been used as a vehicle by Korea's chaebol, which own firms in a variety of industries, to maintain profitable operations in their capitalintensive firms.

The last two decades in Taiwan and Korea represent a confluence of a number of developments that complicate the analysis of how competition from international trade affects the gender wage gap. Trade competition, outward foreign direct investment, and technological upgrading in several industries are all linked in the effort to maintain or extend competitiveness at the firm and industry levels. Empirical studies using the non-neoclassical framework have examined the impact of trade and foreign direct investment on changes in the gender wage gap. In the Taiwan context, Berik (2000) uses industry-level panel data to provide an explicit test of the effect of export orientation in Taiwan on (unadjusted) gender wage ratios. She finds that, after controlling for employment segregation by gender and other industry characteristics, greater export orientation is associated with smaller wage differentials between men and women. However, this result is due to the fact that export orientation has a larger adverse impact on men's wages than women's wages, suggesting the importance of examining absolute wage levels as well as relative wages.

Seguino (2000) finds support for her thesis that divergent trends in the (unadjusted) gender wage ratio in Taiwan and Korea over the 1981-1992 period are related to the differences in the nature of foreign direct investment flows in the two countries. Accordingly, greater capital 
mobility in Taiwan's labor-intensive, female-intensive sectors leaves women workers more vulnerable to losses of bargaining power in wage negotiations. In Korea, however, the government exercised greater control over capital outflows in labor-intensive, export-oriented sectors. Relative to Taiwan, Korean capital was more likely to flow out of capital-intensive, male-dominated sectors. Subsidized credit to export-oriented firms for productivity-enhancing investments also helped to facilitate women's relative wage increases in Korea. In an environment where capital is more mobile, the reality or threat of moving to lower wage sites limits the ability of workers to secure higher wages. An environment of lesser capital mobility, on the other hand, encourages firms to maintain competitiveness by other strategies, such as technological upgrading and improvements in product quality.

Unexamined so far are the effects of technological upgrading that are likely to be differentiated by gender. In a period of technological restructuring, men may to seek to preserve the new, stable, and higher paying jobs for themselves in the face of competition from lowerwaged women workers (Darity 1989). Women, in turn, may experience greater job losses as unskilled jobs disappear, with three possible outcomes: first, women may not find new employment because new jobs require more skills and women may not qualify without training, but from which they are excluded; second, women may get absorbed into reclassified (lower paying) jobs; and third, women may be absorbed into new jobs that are not held by men. Each of these scenarios indicates perpetuation of and perhaps increase in wage discrimination against women workers. While adherents of the non-neoclassical approach do not predict an increase in wage discrimination in technologically dynamic sectors, one could plausibly provide such an account: industries that are undergoing technological upgrading are likely to shed labor associated with the old technology, and hire new, more skilled labor. Such a process is likely to 
intensify job competition among groups of workers. This process may widen the gender wage gap as the emerging employment structure makes it even less likely that women will find employment in higher paying positions, and their longer job queues for such positions will keep their wages in check.

In sum, non-neoclassical studies have either found or predicted adverse effects of greater international openness on the gender wage gap. These studies have explained employment and pay discrimination by sex in the context of employer incentives, the power of established groups of employees, state objectives to maintain export competitiveness, bargaining power, and gender norms. In explaining changes in Taiwan and Korea's gender wage gaps, the redistribution of employment across industries appears to matter less than gender pay discrepancies within industries (Seguino, 2000). A similar conclusion is reached in an analysis by occupation groups rather than industries: pay discrepancies within detailed occupation groups rather than shifts in employment structures across occupations explain much of Taiwan's wage inequality during the 1980s and 1990s (Zveglich and Rodgers 2002). These results imply that women in Taiwan and Korea are not receiving equal pay for work of equal value within industry and occupation groups. Hence we must consider how capital mobility, trade, and technological restructuring affect not only changes in labor demand across sectors, but also persistent pay inequities between men and women within sectors. Although these changes are difficult to disentangle, the following descriptive and regression analyses provide more detail on sectoral patterns in employment and pay differentials and how these differentials are related to competition from international trade.

\section{Methodology}


The empirical analysis determines the extent to which the gender wage gap responds to increased competition from international trade. The basic strategy underlying the empirical approach is to separate the effects of greater openness in international trade from other contemporaneous shocks that are unrelated to international competitiveness. The effect of greater openness in international trade is isolated by controlling for differences in market structure across industries.

Increased openness in international trade is hypothesized to place pressure on firms to reduce discrimination against women. Firms in relatively more concentrated industries are considered to face less domestic pressure to engage in competitive behaviors such as reducing costly discrimination against women, compared to firms in relatively less concentrated industries. Since employers in relatively concentrated industries face less pressure from domestic competition to cut costs, any reduction in the gender wage gap in relatively concentrated industries should be attributed to the competitive forces from international trade. Intuitively, the wage effects from trade openness are identified by comparing the wage impact of trade openness in more concentrated industries to less concentrated industries. This strategy yields an estimate of the impact from greater international competition that controls for other unobserved shocks that are common to all relatively open sectors or all concentrated sectors.

The estimation model, as employed in Black and Brainerd (2000), tests the idea that changes in competitiveness over time affect changes in wage gaps over time. Let $W_{\text {ist }}$ be the average $\log$ wage of workers with sex $s$ in industry $i$ and year $t$, and let $\Delta_{s} W_{i t}$ denote the difference between men and women in average $\log$ wages in industry $i$ and year $t$. Further, let $\Delta_{t}$ denote the difference in any variable between two years within any industry. The estimation equation is: 


$$
\Delta_{t} \Delta_{s} W_{i s t}=\alpha_{0}+\alpha_{1} C_{i}+\alpha_{2}\left(\Delta_{t} M_{i t}\right)+\alpha_{3}\left(C_{i} \times \Delta_{t} M_{i t}\right)+\text { error }
$$

where the dependent variable is the change over time in the average gender log wage gap by industry. The notation $C_{i}$ is the industry-specific measure of domestic concentration, $\Delta_{t} M_{i t}$ is the change over time in the industry-specific import ratio (and alternatively the export ratio), and $C_{i} \times \Delta_{t} M_{i t}$ represents the interaction between industry concentration and the change in the trade share. The coefficient $\alpha_{1}$ represents the effect from domestic concentration, and $\alpha_{2}$ represents the effect from increased exposure to international trade. The final coefficient $\alpha_{3}$ represents the wage gap effect in a sector that is more open and concentrated; it is the estimate of changes in international competitiveness on changes in the wage gap over time. Each variable is disaggregated by detailed industry codes. Regressions are weighted using probability weights based on average-period employment levels by industry. All data used to estimate the model are described in the Data Appendix.

The dependent variable is constructed from time series information on average wages by sex, industry, and year. The above equation is estimated using both average unadjusted wage gaps by industry and average residual wage gaps by industry. The residual wage gap - the portion of the wage gap which cannot be explained by observed productivity differences between men and women—is commonly attributed to wage discrimination against women. To calculate these figures, a human capital earnings function is estimated for male employees in each year. Here, the dependent variable is log monthly earnings. Because the independent variables include $\log$ monthly hours worked, the analysis effectively estimates an hourly-wage equation. ${ }^{6}$ The remaining observable characteristics include a standard set of human capital indicators, such as education, experience, regional locations, and worker status. ${ }^{7}$ Occupation dummy variables are excluded since occupational attainment may involve some degree of labor market discrimination. 
The coefficients from the male regression are used to calculate predicted log wages for male and female workers. ${ }^{8}$ Residual wages are the difference between actual log wages and predicted $\log$ wages, and the residual gender wage gap is the difference between male and female residual wages.

The industry-specific measure of domestic concentration is constructed from Pareto function estimates of concentration across revenue categories and industries. Following Curry and George (1983), the number of firms of size $x$ or larger in a given industry can be written as a Pareto distribution of the following form:

$$
P(x)=\left(x_{0} / x\right)^{\alpha} \quad \text { for } x \text { greater than a minimum size } x_{0}
$$

where $\alpha$ denotes a constant. Taking the logarithm of both sides yields the following estimation equation:

$$
\log P(x)=\alpha \log x_{0}-\alpha \log x
$$

Intuitively, on a log-log scale, the distribution of firms along increasing size categories is described as a downward sloping line with slope $\alpha{ }^{9}$ The steeper the slope coefficient, the less concentrated — or more competitive - the industry. This method can be applied to data that is readily available for many developing countries, including both Taiwan and Korea, whereas other popular indices of concentration have more stringent data requirements. The Pareto function estimates are used to specify domestic concentration as a continuous variable and, alternatively, as a dummy variable. For the latter, industries are ranked in descending order of competitiveness, and industries above a critical breakpoint are assigned a value of zero for nonconcentrated, while industries below a critical breakpoint are assigned a value of one for concentrated. 
To check for robustness in our determination of concentration across industries, the Pareto function is estimated using alternative proxies for size categories and alternative years of data. In particular, revenue size categories are measured by operating receipts for Taiwan and shipments for Korea. Alternatively, asset size categories are measured by assets for Taiwan and paid-in-capital for Korea. For each series the function is estimated with data from a beginning year and an end year. Table 1 presents results for both countries' industry-specific domestic competitiveness using the Pareto function approach applied to revenue size categories using data from a beginning year. Rank correlation coefficients indicate that the rankings do not change much over time and are robust to alternative measures of industry and concentration. ${ }^{10}$

Finally, the import ratio variable is constructed from time series information on the ratio of imports to domestic production (and alternatively, the ratio of exports to domestic production). Trade shares may be a less precise indicator of trade openness compared to measures based on tariffs, non-tariff barriers, and export subsidies, particularly for economies such as Taiwan and South Korea whose governments used an extensive array of trade policies to protect their export and import-substitute sectors. However, even though the tradeables sectors in these countries benefited from government protection, the protection was linked with carefully-structured incentives for competition, thus making trade shares a reasonable indicator of international competitiveness. ${ }^{11}$ In the regression analysis, trade ratios are specified as natural logs, so the coefficients on the trade ratio variables are interpreted as elasticities.

\section{Descriptive Analysis}

Korea is notorious for having one of the lowest gender wage ratios in East Asia. Figure 1 provides wage ratio estimates for selected Pacific Rim economies. In 1990 only Malaysia had a lower wage ratio, and by the late 1990s both Korea and Japan ranked at the bottom with ratios of 
58\%. Taiwan's gender wage ratio during the 1990s compared favorably with other East Asian economies but stood below that of the industrialized countries, including Australia, New Zealand, and the United States. According to the Figure, during the 1990s the wage ratio generally rose across countries.

Turning next to more detailed trends in the Taiwan and Korean gender wage ratios, Figure 2 shows that without adjusting for any gender differences in skills, the female-male wage ratio in manufacturing fell considerably for much of the period, from $66 \%$ in 1981 to $60 \%$ in 1993 , before rising again to $67 \%$ by 1999 . In contrast, women's relative wages in nonmanufacturing industries remained fairly stable at roughly $71 \%$ until the mid- 1990 s, when they started to climb by about a percentage point a year. Once gender differences in education and experience are taken into account, women's relative earnings fall sharply until the mid-1990s, particularly in manufacturing, with a recovery in both sectors during the late 1990 s. $^{12}$ Patterns in Korean gender wage ratios are reported in the second panel. Like Taiwan, Korean women's relative wages are lower in manufacturing industries than in non-manufacturing industries, but unlike Taiwan, Korea's female to male wage ratio rose fairly steadily throughout the period in both parts of the economy. Once gender skill differentials are taken into account, residual wage ratios are again lower in manufacturing than elsewhere in the economy, with some upward trend in the early to mid-1980s and not much movement thereafter. Notably, unadjusted wage ratios are quite low in Korea relative to Taiwan while residual wage ratios are considerably higher in Korea. This result occurs because observed worker characteristics explain a larger portion of the gender wage differential in Korea than they do in Taiwan, so once worker characteristics are taken into account, the Korean wage differential narrows more for Korea than for Taiwan. ${ }^{13}$ 
To illustrate how competitive forces from international trade might be related to women's relative wages, Figure 3 plots the manufacturing-sector residual wage ratios against aggregate manufacturing trade ratios in both Taiwan and Korea. ${ }^{14}$ In Taiwan, the period of falling residual wage ratios coincides with a fairly steady increase in trade ratios, while the recovery in women's relative residual wages toward the end of the period coincides with a flattening in both trade ratios. These patterns, which appear to be slightly stronger for the import series, suggest that increasing openness over time is negatively related to patterns in women's relative earnings. In Korea, the slow but steady increase in the residual wage ratio contrasts noticeably with a decline in the aggregate export ratio for most of the period, while there is no clear relationship with imports. ${ }^{15}$

Competitive forces from domestic market structures may also have played a role in determining women's relative wages in the manufacturing sector. Figure 4 reports both wage ratios and wage levels by industry concentration for Taiwan and Korea. For Taiwan, Panel A shows that both the unadjusted and residual wage ratios are higher in concentrated industries than in non-concentrated industries. Further analysis (Panel B) shows that wage levels for both men and women are higher in concentrated industries than non-concentrated industries-though men in non-concentrated industries earn substantially more than women in concentrated industries. ${ }^{16}$ The most likely explanation is the ability of firms in concentrated industries to pay higher wages to all workers. Concentrated industries include electronics, chemical products, and chemical materials, which are technologically dynamic industries that have the capability to upgrade products (Chen and Chen 1995; Amsden and Chu 2002). Chen and Chen (1995) infer technological capability from sectoral patterns in foreign direct investment. Sectors in which outward foreign direct investment to high wage economies exceed that directed to low wage 
economies, are sectors where firms are engaged in efforts to expand markets by differentiating products from home production. These industries are also likely to have firms engaged in internal restructuring in Taiwan, introducing new product lines to replace the transplanted ones, and reemploying skilled employees in newly created departments. Several of the nonconcentrated industries, however, have limited capacity to upgrade products or pay higher wages. These industries experience absolute declines in output as firms replicate home production in low-wage economies in South East Asia.

Trends over time are similar in Taiwan's concentrated and non-concentrated industries. Both experienced a steep decline in wage ratios in the 1980s, followed by relatively flat wage ratios in the early 1990s, and a slight rise in the late 1990s. This commonality across industries suggests that wage trends are shaped by forces other than changes in industrial policy or industrial structure, which were both relatively stable during the period. In the latter half of 1990s, the residual wage ratio in non-concentrated industries began to converge to the residual wage ratio in concentrated industries. Panel B shows that this convergence reflects the fact that men in non-concentrated industries experienced virtually no wage growth after 1995, while wages of women in non-concentrated industries continued to rise. In contrast, the Korean residual wage ratio in non-concentrated industries has been relatively flat while the ratio in concentrated industries has been rising (Panel C). Panel D shows that, similar to Taiwan, men and women in Korea's concentrated industries earn more than their counterparts in nonconcentrated industries. ${ }^{17}$ Comparison of Panels B and D also shows that men and, especially women, in concentrated industries were better insulated from the wage-depressing effects of the Asian crisis. 
Changes in labor demand may provide further insight into the changes in the gender wage gaps. To shed some light on quantity effects during the period of analysis, Tables 2 (Taiwan) and 3 (Korea) present more detailed information on employment shares by gender, wage ratios, and trade shares across sectors for the 1980-99 period. Within manufacturing Taiwan and Korea share some similar trends, in that both female and male employees recorded dramatic shifts out of low-skilled jobs_especially textiles and garments-into higher-skilled jobs-especially electrical and electronic equipment. In Taiwan in 1981, over half of women's employment in manufacturing (62\%) was in textiles and apparel, electronics, and plastics. In 1999 women's employment continued to be concentrated in the three major employers of women-now, electronics, textiles and apparel, and metals (basic and fabricated), which accounted for $61 \%$ of women's employment. Men's employment was more evenly distributed across sectors than women's, but became more concentrated in a few sectors over time. The top three employers of men accounted for 38\% of male employment in 1981 and 50\% in 1999. Employment patterns in Korea are similar. The largest employers of women were textiles, apparel, and electronics in both 1980 and 1998. In contrast to Taiwan, however, the concentration of women in these three industries declined over time. The top three employers of men accounted for a larger share of male employment in 1998 (42\%) than in 1980 (30\%). In both economies, the industries where women's employment is concentrated are also among the most female intensive sectors.

Focusing on the largest employers, Tables 2 and 3 further show that in both countries import competition in textiles and apparel is associated with greater decline in job opportunities for women than for men. At the same time, this industry has become more export-oriented in Taiwan, while in Korea only textiles experienced an increase in its export share, in both cases most likely on the basis of higher quality products. ${ }^{18}$ Consistent with the decline in labor 
demand, the residual wage ratio in Taiwan's textile and apparel industries declined over time, and fell in textiles but was relatively constant in Korea's apparel industry. The lower wage ratio may reflect not only that the jobs held by women are rapidly disappearing but also that women are being absorbed into reclassified, lower paying positions in textiles and apparel as the industry undergoes restructuring.

The electrical and electronic goods industry, on the other hand, has come to provide a growing share of the jobs held by women, and a greater share than it does for men in both countries. The expansion in labor demand in this concentrated industry was accompanied by both greater export orientation and import competition in Korea, while in Taiwan the industry's export share and import share have slightly declined. ${ }^{19}$ At the same time, the residual wage ratio in this industry rose substantially in Korea, while it was fairly constant in Taiwan. The flat residual wage ratio in Taiwan suggests that women are being absorbed into lower paid jobs and are unable to secure wage gains relative to men, in spite of the growth in job opportunities for women and technological dynamism in this sector. In Korea, a broadening of employment options may have helped women to secure wage gains in this sector.

Table 2 shows that among the non-concentrated industries, both women's and men's employment opportunities declined in the wood products, miscellaneous manufactured goods, and plastics industries. These sectors have been subject to relocation in South East Asia and mainland China and are now the source of rising import competition in Taiwan. Except in the plastics industry, these sectors experienced growth in their export shares along with rising import shares, which suggests that they continue to be competitive in export markets. Nonetheless, the residual wage ratio has declined in all of the non-concentrated industries, not only in industries undergoing capital flight, which may indicate the effects of threat of capital mobility on 
women's relative wages. Table 3 shows that Korean women's and men's employment opportunities also declined in several nonconcentrated industries, and these declines are associated with rising import shares. However, these changes in employment and trade are not associated with relative wage declines as they are in Taiwan.

\section{Regression Analysis}

Estimation results are found in Table 4 (Taiwan) and Table 5 (Korea). The results are reported as changes in the male-female wage gap measured in log points. The male-female gap may be converted to a female to male ratio by exponentiating its negative. Both tables report results from estimations where domestic concentration is specified as a time-invariant dummy variable (columns 1 and 3) and as a time-invariant continuous variable (columns 2 and 4). Both tables report results for the full period of analysis (columns 1 and 2), and to avoid possible distortions from the East Asian financial crisis, for the period ending in 1996 (columns 3 and 4).

A strong result emerges for Taiwan: an increase in international competitiveness over time in concentrated industries is associated with a widening in the gender wage gap. This result is robust to alternative end years in estimation, alternative weighting methods, and most alternative specifications of industry concentration. However, the result holds only when trade openness is measured using the ratio of imports to output by sector. Table 4 shows that after controlling for worker productivity characteristics, an increase in international competitiveness from imports in concentrated industries $\left(C \times \Delta_{t} M_{t}\right)$ between 1981 and 1999 is associated with a statistically significant increase in the residual wage gap. The result could imply that wage discrimination against women rises in the face of increased competition from imports. While an increase in competitiveness from exports in concentrated industries $\left(C \times \Delta_{t} X_{t}\right)$ also appears to be associated with an increase in the residual wage gap, the result is not significant. For unadjusted 
wage gaps in Panel A, the main result holds, but the coefficient estimate on $C \times \Delta_{t} M_{t}$ for the 198199 period loses its precision once concentration is measured using a continuous variable.

When 1996 is used as the endpoint, increased competitiveness from imports in concentrated industries is similarly associated with wider wage gaps across specifications for both the residual and unadjusted wage gaps. This result suggests that the main conclusion is not sensitive to any spillover effects from the financial crisis. In additional tests for robustness (not reported), the positive coefficient on the interaction between concentration and the import ratio for both the unadjusted and residual wage gap regressions maintains its precision when concentration is measured using the assets-based Pareto estimates, regardless of the end year of the estimation period. A similar robustness across alternative measures of concentration is in evidence when 1997 is used as the end year. When concentration is measured in terms of the number of enterprises/output, the estimates for $C \times \Delta_{t} M_{t}$ are more sensitive to the end year chosen and only become significant in most specifications that use 1996 and 1997 as the end year.

The conclusion that trade competition in concentrated sectors is positively associated with the gender wage gap still holds for Korea, but the results are not as strong, and competition from exports appears to matter more than competition from imports. The first panel of Table 5 shows that increased competitiveness from exports is associated with a widening in the unadjusted wage gap in concentrated industries when domestic concentration is specified as a continuous variable but not as a dummy variable. This conclusion also holds for the residual wage gap for the 1980-98 period only. In the shorter period that controls for the effects of the East Asian crisis, it appears that competitiveness from imports, rather than exports, is positively associated with widening residual wage gaps. Similar conclusions are reached in robustness tests when concentration is measured using the number of establishments/output by sector. 


\section{Conclusion}

This study has examined the impact of international competitiveness on industry-level gender wage gaps in Taiwan and Korea's manufacturing sectors between 1980 and 1999. During much of this period the gender wage gap in Taiwan widened, only to begin a recovery in the mid-1990s. By contrast, Korea's gender wage gap narrowed slowly and steadily through most of the period. While both countries are highly open to trade, trends in trade ratios also diverged over this period, with Taiwan becoming relatively more exposed to international competitive pressures than Korea. Taiwan experienced a near continuous rise in both export and import shares of its manufactured output, while Korea experienced a decline in its export share for much of the period along with a flat trend in its import share. Taiwan's greater trade openness has been driven by not only increasing imports of labor-intensive goods from South East Asia-which has become the center of Taiwan's investments-but also by efforts to technologically upgrade the export sector. Both countries had a relatively stable industrial structure and policy during the period, Taiwan being the more competitive and market-oriented of the two. The descriptive analysis, therefore, has shown that in Taiwan rising trade openness and a continued highly competitive industrial structure are associated with rising gender wage inequality. By contrast, Korea's declining total trade openness, coupled with its less competitive industrial structure, is associated with a gradual narrowing of the manufacturing-sector gender wage gap.

The study specifically aimed to test the dynamic implications of Becker's theory that greater competition erodes wage discrimination against women. The empirical analysis centered on the effects of trade on the gender residual wage gap in relatively concentrated industries. Residual wage gaps, which account for gender differences in observed productivity 
characteristics, are often attributed to wage discrimination against women. In concentrated industries, employers face less pressure from domestic competition to cut costs, so any reduction in the residual wage gap could then be attributed to the competitive forces from international trade rather than to domestic pressures. Consistent with the descriptive analysis, industry-level wage-gap regressions do not support Becker's theory. Quite the contrary, results indicate that increasing competitiveness from trade is positively associated with the residual wage gap in concentrated industries in both countries. The more robust regression results emerge for Taiwan. They show that from 1981 to 1999 , rising import shares are associated with rising wage discrimination against women workers in concentrated industries, which include the largest employer and major exporter sectors, such as the textiles/apparel and the electronics/electrical industries. For Korea, a slight decline in export orientation is weakly associated with a reduction in wage discrimination against female workers in concentrated industries between 1980 and 1998.

The results for Taiwan may be explained in light of the restructuring in Taiwan's laborintensive, export-oriented industries, which underwent de-industrialization and layoffs following the expansion of foreign direct investment in the same industries in mainland China and in other South East Asian countries. The sectors that are more successful in technological upgrading and capturing new export markets may also be the ones that disproportionately employ higher-paid, male workers. However, rising import competition in previously export-oriented sectors may be associated with more layoffs for women than men and greater downward pressure on women's wages in an environment that affords little protection for workers. Female workers thus appear to disproportionately bear the costs of greater exposure to international trade. In the Korean case, the long-standing patriarchal patterns of social and business organization may have eroded 
as the international pressures weakened--when capital was less mobile and export shares declined--and employers were able to resist the impetus to underpay women. The comparative analysis of two highly successful export economies thus shows that increasing international openness does not ensure an improvement in women's relative economic status.

The major policy initiative to ensure that gains from globalization are shared more equally between men and women would be to pass and enforce anti-discrimination legislation. This initiative would not only open up access to jobs for women in a wider range of occupations and industries than the ones they are concentrated in but also ensure equal pay for equal work. The political economic context, however, indicates the enormous difficulty of passing, let alone enforcing, such legislation. Taiwan has had an equal pay for equal work clause on the books since enacting the 1984 Labor Standards Law, but evidence in Chiu (1993) shows that firms were less likely to comply with the equal pay clause than they were with other measures in the Labor Law. Taiwan still has no equal opportunity in employment legislation on the books. Chen's (2001) discussion of the "Gender Equal Employment" Bill (GEEB), first introduced in the parliament in 1989, shows the resistance to the bill that came from business groups and economic ministries of the government entrusted with ensuring continued export competitiveness. The bill is a comprehensive law aimed to protect women's equal rights in the labor market. It prohibits employment discrimination in various forms and introduces provisions such as parental leave to reduce the conflict between employment and family responsibilities. Chen states that representatives of business groups threatened to move firms out of Taiwan or not hire women, should the bill be passed, and in the recessionary environment of the early 1990 s these threats were effective in preventing the passage of this bill into law. The threats suggest that wage discrimination against women workers continues to be an important means for 
continued export competitiveness, in spite of the manufacturing industry's shift from the lowwage route to maintaining export competitiveness to a route where competition is more on the basis of export product quality. In the Korean case, the government has had equal opportunity in employment legislation on the books since 1987. Additional labor reforms in 1987 relaxed the government's control on unions and liberalized collective bargaining procedures. These changes resulted in greater pressure on firms to comply with existing labor standards they had previously ignored, including an equal pay for equal work clause. The slight decline in export orientation and support from the government's industrial policy in concentrated industries may have facilitated better enforcement of this anti-discrimination legislation during the period of analysis, helping to explain the decline in wage discrimination in export-oriented, concentrated industries. 


\section{Data Appendix}

Taiwan's standard industry classification has undergone six revisions since its inception in 1967. The first year of data used in this study is based on the second revision. Revisions 3 (1983), 4 (1987), and 6 (1996) contain changes primarily at the three-digit level, which are readily reconcilable with earlier versions for the two-digit classifications. Only the fifth revision, published in 1991, contains major changes at the one- and two-digit levels, but this change only affects the labor data from 1993 onwards. Korea's standard industry classification has undergone seven revisions since its establishment in 1963. The first year of data used in this study is based on the fourth revision. Revisions 5 (1984) and 7 (1998) contain changes primarily at the fourdigit and five-digit levels, which are readily reconcilable with earlier versions for three-digit classifications (Kang, 2001). Only the sixth revision, published in 1991, contains major changes at all levels of aggregation, but this change only affects the labor data from 1993 onward. Both the Taiwan and Korea industry classification systems are based on international standards. We categorize manufacturing industries by two-digit codes for Taiwan and three-digit codes for Korea since the labor data record industry of employment at that level. As shown in Appendix Table 1, some additional aggregation was necessary to provide consistency over time and to avoid small cell sizes in the calculation of average wages by gender and industry. ${ }^{20}$

Appendix Table 2 summarizes the key variables and their sources. The labor data for Taiwan are from the Manpower Utilization Survey for the period 1981-1999. This householdlevel survey contains detailed information on earnings, employment, and worker characteristics. The Korean labor data come from the Occupational Wage Survey (OWS), but due to constraints on data availability, the sample is limited to the years $1980,1983,1986,1989,1992,1994,1996$, and 1998. This establishment-level survey similarly contains comprehensive labor-market 
information for individual workers. Surveyed establishments are selected using a stratified random sampling method from establishments with at least 10 workers. In addition to small firms, the OWS also excludes the self-employed, family workers, temporary workers, and public-sector workers. Wages for both countries are deflated using the consumer price index.

The US-dollar value of exports and imports by 4-digit International Standard Industrial Category (ISIC) are from the International Economic Data Bank (IEDB) for the period 19801999 for both Taiwan and Korea. IEDB converts UN trade data from Standard International Trade Categories to ISIC using concordance tables based on the structure of trade and production in the two economies. The trade ratios are relative to a measure of gross production by industry. For Taiwan, the data are gross receipts by 2-digit level Taiwan industry codes (revision 6) in new Taiwan dollars. The production data are converted to US dollars using the annual average exchange rate. The trade data are regrouped according to 2-digit Taiwan industry codes (revision 6) using a linking scheme based on concordance tables published by the United Nations and the government of Taiwan. For Korea, the production data are gross output in US dollars by 3-digit ISIC codes from the UNIDO Industrial Statistics Database.

For Taiwan, the data for estimating domestic competitiveness come from the Industrial and Commercial Census. This census, conducted once every five years, contains data by disaggregated industry on the number of enterprises in various operating-receipts categories of increasing size. The census also has data on the number of enterprises by asset size categories and by industry. We use both series in alternative estimates of the Pareto function for a base year (1981) and an end year (1996). For Korea, the data for estimating domestic competitiveness come from the Korean Industrial Census. This census, conducted once every five years, contains data by disaggregated industry on the number of establishments in various shipment-value 
categories of increasing size. The census also has data by industry on the number of establishments by asset size categories, as indicated by paid-in-capital. Both series are used in alternative estimates of the Pareto function for a base year (1983) and an end year (1998). 


\section{Appendix Table 1: Consistent Manufacturing Aggregates by Standard Industrial Classification Codes, Taiwan and Korea}

\begin{tabular}{|c|c|c|c|c|c|}
\hline Taiwan Manufacturing Industry Aggregates & $\begin{array}{l}\text { Rev. 2-4 } \\
(1981-92)\end{array}$ & $\begin{array}{l}\text { Rev. 5-6 } \\
(1993-99)\end{array}$ & Korean Manufacturing Industry Aggregates & $\begin{array}{l}\text { Rev. 4-5 } \\
(1980-92) \\
\end{array}$ & $\begin{array}{l}\text { Rev. 6-7 } \\
(1993-98)\end{array}$ \\
\hline 1. Food, Beverage, and Tobacco Manufactures & 20,21 & 11,12 & 1. Food Manufactures & 311 & $151-154$ \\
\hline 2. Textile Industries; Manufacture of Wearing & & & 2. Beverage and Tobacco Manufactures & 313,314 & 155,160 \\
\hline Apparel and Accessories & 22,23 & 13,14 & 3. Textile Industries. & 321 & $171-173$ \\
\hline 3. Manufacture of Leather, Fur, and Related Products & 24 & 15 & 4. Manufacture of Wearing Apparel & 322 & 181 \\
\hline $\begin{array}{l}\text { 4. Manufacture of Wood Products, Bamboo Products, } \\
\text { and Furniture }\end{array}$ & 25 & 16,17 & $\begin{array}{l}\text { 5. Manufacture of Leather, Fur, Related Products, } \\
\text { and Footwear (except Rubber or Plastic Footwear) }\end{array}$ & 323,324 & $182,191,192$ \\
\hline 5. Manufacture of Paper and Paper Products; Printing & 26 & 18,19 & 6. Manufacture of Wood Products and Cork Products & 331 & 201,202 \\
\hline $\begin{array}{l}\text { 6. Manufacture of Chemical Materials; Manufacture } \\
\text { of Petroleum and Coal Products }\end{array}$ & 27,29 & 21,23 & $\begin{array}{l}\text { 7. Manufacture of Furniture and Fixtures } \\
\text { 8. Manufacture of Paper and Paper Products }\end{array}$ & $\begin{array}{l}332 \\
341\end{array}$ & $\begin{array}{l}361 \\
210\end{array}$ \\
\hline 7. Manufacture of Chemical Products & 28 & 22 & 9. Printing and Publishing & 342 & 221,222 \\
\hline 8. Manufacture of Rubber Products & 30 & 24 & 10. Manufacture of Chemical Materials & 351 & 241 \\
\hline 9. Manufacture of Plastic Products & 31 & 25 & 11. Manufacture of Chemical Products & 352 & 242,243 \\
\hline 10. Manufacture of Non-metallic Mineral Products & 32 & 26 & 12. Manufacture of Petroleum and Coal Products & 353,354 & $231-233$ \\
\hline 11. Basic Metal Industries; Manufacture of Fabricated & & & 13. Manufacture of Rubber Products & 355 & 251 \\
\hline Metal Products & 33,34 & 27,28 & 14. Manufacture of Plastic Products & 356 & 252 \\
\hline $\begin{array}{l}\text { 12. Manufacture and Repair of Machinery and } \\
\text { Equipment }\end{array}$ & 35 & 29 & $\begin{array}{l}\text { 15. Manufacture of Pottery, China, and Glass Products } \\
\text { 16. Manufacture of Other Non-metallic }\end{array}$ & 361,362 & 261 \\
\hline 13. Manufacture and Repair of Electrical and & & & Mineral Products & 369 & 269 \\
\hline $\begin{array}{l}\text { Electronic Machinery and Equipment } \\
\text { 14. Manufacture and Repair of Transport Equipment }\end{array}$ & $\begin{array}{l}36 \\
37\end{array}$ & $\begin{array}{l}31 \\
32\end{array}$ & $\begin{array}{l}\text { 17. Iron and Steel Basic Industries; Non-Ferrous } \\
\text { Metal Basic Industries }\end{array}$ & 371,372 & $271-273$ \\
\hline 15. Manufacture of Precision Instruments & 38 & 33 & 18. Manufacture of Fabricated Metal Products & 381 & 281,289 \\
\hline 16. Manufacture of Miscellaneous Industrial & 39 & 39 & 19. Manufacture of Machinery and Equipment & 382 & $291-293$ \\
\hline & & & Machinery and Equipment & 383 & $\begin{array}{l}300,311-315 \\
319,321-323\end{array}$ \\
\hline & & & 21. Manufacture of Transport Equipment & 384 & $\begin{array}{c}341-343 \\
351-353,359\end{array}$ \\
\hline & & & 22. Manufacture of Precision Instruments & 385 & 331-333 \\
\hline & & & 23. Manufacture of Miscellaneous Industrial Products & 390 & $369,371,372$ \\
\hline
\end{tabular}

Sources: DGBAS $(1987,1991)$ and NSO (2001). 


\section{Appendix Table 2: Key Variable Definitions and Data Sources}

\begin{tabular}{|c|c|c|c|}
\hline Variable & Description & Date Source: Taiwan & Date Source: Korea \\
\hline \multicolumn{4}{|l|}{ Real Wage: } \\
\hline Nominal Wage & $\begin{array}{l}\text { Average wages and average } \\
\text { residual wages by sex and industry }\end{array}$ & $\begin{array}{l}\text { Manpower Utilization Survey, } \\
\text { DGBAS } \\
\text { 1981-1999 }\end{array}$ & $\begin{array}{l}\text { Occupational Wage Survey, } \\
\text { Ministry of Labor } \\
1980,83,86,89,92,94,96,98\end{array}$ \\
\hline Wage Deflator & Consumer price index & $\begin{array}{l}\text { Monthly Bulletin of Statistics, } \\
\text { DGBAS (various) } \\
\text { 1981-1999 }\end{array}$ & $\begin{array}{l}\text { NSO Online Statistical Database, } \\
\text { NSO } \\
1980-1998\end{array}$ \\
\hline \multicolumn{4}{|l|}{ Trade Shares: } \\
\hline Imports & CIF value by industry & $\begin{array}{l}\text { International Economic Data Bank, } \\
\text { ANU (2001) } \\
\text { 1981-1999 }\end{array}$ & $\begin{array}{l}\text { International Economic Data Bank, } \\
\text { ANU (2001) } \\
\text { 1980-1998 }\end{array}$ \\
\hline Exports & FOB value by industry & $\begin{array}{l}\text { International Economic Data Bank, } \\
\text { ANU (2001) } \\
1981-1999\end{array}$ & $\begin{array}{l}\text { International Economic Data Bank, } \\
\text { ANU (2001) } \\
1980-1998\end{array}$ \\
\hline Domestic Production & $\begin{array}{l}\text { Gross receipts (Taiwan), gross } \\
\text { output (Korea) by industry }\end{array}$ & $\begin{array}{l}\text { National Income Accounts, } \\
\text { DGBAS } \\
1981-1999\end{array}$ & $\begin{array}{l}\text { Industrial Statistics Database, } \\
\text { UNIDO (2000) } \\
\text { 1980-1998 }\end{array}$ \\
\hline Exchange Rate & Average exchange rate & $\begin{array}{l}\text { Financial Statistics (IMF), } \\
\text { Central Bank of China (various) } \\
\text { 1981-1999 }\end{array}$ & Not applicable \\
\hline Industry Concentration: & $\begin{array}{l}\text { Pareto function estimates by } \\
\text { industry }\end{array}$ & $\begin{array}{l}\text { Industrial and Commercial Census, } \\
\text { DGBAS } \\
1981,1996\end{array}$ & $\begin{array}{l}\text { Korean Industrial Census, } \\
\text { NSO } \\
1983,1998\end{array}$ \\
\hline
\end{tabular}


Table 1: Pareto Function Estimates of Domestic Competitiveness For Taiwan and Korea

(Industry ranking in descending order of competitiveness)

\begin{tabular}{|c|c|c|c|}
\hline Taiwan & 1981 & Korea & 1983 \\
\hline 1. Basic Metal Industries; Fabricated Metal Products & -0.77 & 1. Furniture and Fixtures & -0.75 \\
\hline 2. Wood Products, Bamboo Products, and Furniture & -0.76 & 2. Miscellaneous Industrial Products & -0.73 \\
\hline 3. Machinery and Equipment & -0.76 & 3. Wood Products and Cork Products & -0.73 \\
\hline 4. Paper and Paper Products; Printing & -0.71 & 4. Printing and Publishing & -0.71 \\
\hline 5. Miscellaneous Industrial Products & -0.71 & 5. Wearing Apparel & -0.66 \\
\hline 6. Plastic Products & -0.67 & 6. Fabricated Metal Products & -0.65 \\
\hline 7. Food, Beverage, and Tobacco Manufactures & -0.62 & 7. Plastic Products & -0.61 \\
\hline 8. Textile Industries; Wearing Apparel \&Accessories & -0.61 & 8. Machinery and Equipment & -0.58 \\
\hline 9. Non-metallic Mineral Products & -0.61 & 9. Other Non-metallic Mineral Products & -0.57 \\
\hline 10. Chemical Products & -0.58 & 10. Precision Instruments & -0.57 \\
\hline 11. Leather, Fur, and Related Products & -0.56 & 11. Leather, Fur, Related Products, and Footwear & -0.54 \\
\hline 12. Transport Equipment & -0.53 & 12. Textile Industries & -0.54 \\
\hline 13. Rubber Products & -0.52 & 13. Pottery, China, and Glass Products & -0.53 \\
\hline 14. Electrical, Electronic Machinery \& Equipment & -0.51 & 14. Food Manufactures & -0.47 \\
\hline 15. Precision Instruments & -0.51 & 15. Beverage and Tobacco Manufactures & -0.45 \\
\hline \multirow[t]{8}{*}{ 16. Chemical Materials, Petroleum, and Coal Products } & -0.26 & 16. Paper and Paper Products & -0.44 \\
\hline & & 17. Transport Equipment & -0.40 \\
\hline & & 18. Electrical, Electronic Machinery \& Equipment & -0.37 \\
\hline & & 19. Rubber Products & -0.35 \\
\hline & & 20. Chemical Products & -0.24 \\
\hline & & 21. Iron and Steel, Non-Ferrous Metal Industries & -0.23 \\
\hline & & 22. Chemical Materials & -0.22 \\
\hline & & 23. Petroleum and Coal Products & -0.04 \\
\hline
\end{tabular}

Note: Figures report the coefficient estimates of Pareto functions using data on number of enterprises by size categories of operating receipts (Taiwan) or shipments (Korea). 
Table 2: Employment, Residual Wage, and Trade Ratios by Industry Concentration, Taiwan: 1981-1999 (In Percentage Points)

\begin{tabular}{|c|c|c|c|c|c|c|c|c|c|}
\hline & \multicolumn{2}{|c|}{ Female Employment Share } & \multicolumn{2}{|c|}{ Male Employment Share } & \multicolumn{2}{|c|}{ Percent Female } & \multirow{2}{*}{$\begin{array}{l}\text { DResidual } \\
\text { Wage Ratio } \\
\text { 1999-1981 }\end{array}$} & \multirow{2}{*}{$\begin{array}{c}\Delta \text { Import } \\
\text { Ratio } \\
1999-1981\end{array}$} & \multirow{2}{*}{$\begin{array}{c}\Delta \text { Export } \\
\text { Ratio } \\
1999-1981\end{array}$} \\
\hline & $\begin{array}{r}\text { Base } \\
1981 \\
\end{array}$ & $\begin{array}{c}\text { Change } \\
1999-1981\end{array}$ & $\begin{array}{l}\text { Base } \\
1981 \\
\end{array}$ & $\begin{array}{c}\text { Change } \\
1999-1981\end{array}$ & 1981 & 1999 & & & \\
\hline \multicolumn{10}{|l|}{ Non-Concentrated Industries } \\
\hline Basic Metal; Fabricated Metal & 3.3 & 4.9 & 17.8 & 3.7 & 12.6 & 21.1 & -5.9 & -6.7 & 9.5 \\
\hline Wood Products & 4.1 & -1.4 & 8.2 & -4.2 & 28.1 & 32.1 & -3.7 & 24.2 & 3.1 \\
\hline Machinery and Equipment & 1.4 & 1.5 & 8.3 & 0.7 & 11.6 & 18.4 & -3.3 & 39.8 & 243.4 \\
\hline Paper; Printing & 2.3 & 1.4 & 5.0 & 0.2 & 26.7 & 33.3 & -3.1 & 12.8 & 3.5 \\
\hline Misc. Industrial Products & 6.7 & -2.6 & 3.9 & -1.5 & 57.5 & 54.5 & -1.0 & 8.6 & 6.1 \\
\hline Plastic Products & 8.6 & -2.9 & 6.6 & -1.1 & 50.2 & 41.9 & -13.9 & 6.6 & -14.2 \\
\hline \multicolumn{10}{|l|}{ Concentrated Industries } \\
\hline Food, Beverage, and Tobacco & 5.1 & 0.2 & 7.2 & -1.3 & 35.7 & 38.7 & -2.5 & 12.4 & -6.4 \\
\hline Textile and Apparel & 36.1 & -17.5 & 9.7 & -3.2 & 74.4 & 66.6 & -11.5 & 8.2 & 25.1 \\
\hline Non-metallic Mineral Products & 4.5 & -1.7 & 5.9 & -1.5 & 37.3 & 30.5 & -8.5 & 10.3 & -4.8 \\
\hline Chemical Products & 1.4 & 0.8 & 2.4 & -0.2 & 31.5 & 41.5 & 3.9 & 7.7 & 8.3 \\
\hline Leather, Fur, Related Products & 4.4 & -2.7 & 2.5 & -1.5 & 57.8 & 53.5 & -14.5 & 13.5 & -67.4 \\
\hline Transport Equipment & 1.7 & 1.6 & 6.0 & 0.3 & 17.9 & 26.5 & 2.6 & 15.0 & 9.5 \\
\hline Rubber Products & 0.9 & 1.7 & 1.2 & 0.4 & 36.8 & 52.6 & 2.4 & -2.1 & -8.1 \\
\hline Electrical, Electronic & 17.3 & 16.5 & 10.0 & 9.0 & 57.5 & 55.5 & -2.8 & -0.5 & -8.6 \\
\hline Precision Instruments & 1.4 & -0.4 & 1.6 & -0.7 & 41.0 & 44.1 & -6.4 & 282.9 & 62.0 \\
\hline Chemical Materials, Petroleum & 0.8 & 0.8 & 3.6 & 0.8 & 14.8 & 20.3 & -6.6 & 11.5 & 18.6 \\
\hline
\end{tabular}


Table 3: Employment, Residual Wage, and Trade Ratios by Industry Concentration, Korea: 1980-1998 (In Percentage Points)

\begin{tabular}{|c|c|c|c|c|c|c|c|c|c|}
\hline & \multicolumn{2}{|c|}{ Female Employment Share } & \multicolumn{2}{|c|}{ Male Employment Share } & \multicolumn{2}{|c|}{ Percent Female } & \multirow{3}{*}{$\begin{array}{c}\Delta \text { Residual } \\
\text { Wage Ratio } \\
1998-1980\end{array}$} & \multirow{3}{*}{$\begin{array}{c}\Delta \text { Import } \\
\text { Ratio } \\
1998-1980\end{array}$} & \multirow{3}{*}{$\begin{array}{c}\Delta \text { Export } \\
\text { Ratio } \\
1998-1980\end{array}$} \\
\hline & Base & Change & Base & Change & & & & & \\
\hline & 1980 & 1998-1980 & 1980 & $1998-1980$ & 1980 & 1998 & & & \\
\hline \multicolumn{10}{|l|}{ Non-Concentrated Industries } \\
\hline Furniture and Fixtures & 0.3 & 1.0 & 0.9 & 0.1 & 25.0 & 31.0 & 3.6 & -2.3 & 2.7 \\
\hline Misc. Industrial Products & 4.6 & -1.7 & 2.4 & -0.5 & 63.4 & 35.3 & 6.3 & -0.6 & 9.0 \\
\hline Wood Products and Cork & 1.4 & -0.2 & 2.8 & -1.2 & 30.3 & 19.6 & 1.0 & 31.2 & -34.2 \\
\hline Printing and Publishing & 1.0 & 1.3 & 2.4 & 0.7 & 27.7 & 21.1 & -7.0 & -1.6 & -4.8 \\
\hline Wearing Apparel & 18.4 & -8.3 & 4.2 & -2.2 & 80.0 & 64.4 & 0.5 & 8.2 & -40.4 \\
\hline Fabricated Metal Products & 2.2 & 0.5 & 8.0 & -3.6 & 19.8 & 17.9 & 13.4 & -12.9 & -14.6 \\
\hline Plastic Products & 0.8 & 0.8 & 1.5 & 1.3 & 33.3 & 17.2 & 0.6 & 2.4 & -18.4 \\
\hline Machinery and Equipment & 0.6 & 3.9 & 6.6 & 4.4 & 7.8 & 12.8 & 10.9 & -83.8 & 21.8 \\
\hline Other Non-metallic Mineral & 0.9 & 1.4 & 4.4 & -1.8 & 16.0 & 23.8 & -8.8 & -0.1 & -10.9 \\
\hline Precision Instruments & 1.4 & 0.4 & 1.3 & -0.1 & 48.8 & 33.5 & 3.6 & 31.1 & 18.5 \\
\hline Leather, Fur, Related Products & 2.8 & 0.3 & 2.8 & -1.2 & 47.5 & 41.5 & -14.7 & -16.5 & 14.4 \\
\hline Textile Industries & 30.5 & -15.7 & 11.3 & -5.1 & 71.0 & 45.9 & -5.4 & 7.6 & 41.8 \\
\hline Pottery, China, and Glass & 1.5 & -1.2 & 2.2 & -1.2 & 37.4 & 8.9 & 21.0 & 11.1 & 2.0 \\
\hline \multicolumn{10}{|l|}{ Concentrated Industries } \\
\hline Food Manufactures & 5.1 & 4.8 & 5.6 & -0.6 & 45.0 & 40.9 & 9.2 & -2.0 & -1.8 \\
\hline Beverage and Tobacco & 0.5 & 0.5 & 1.5 & 0.9 & 22.3 & 12.5 & 21.8 & 3.1 & 0.6 \\
\hline Paper and Paper Products & 1.1 & 0.0 & 2.5 & 0.5 & 29.0 & 11.5 & 8.1 & -6.6 & 14.6 \\
\hline Transport Equipment & 0.7 & 3.4 & 7.8 & 5.9 & 7.1 & 9.5 & 11.2 & -31.7 & -0.1 \\
\hline Electrical, Electronic & 16.1 & 11.0 & 10.8 & 6.9 & 57.4 & 35.2 & 13.0 & 17.3 & 36.2 \\
\hline Rubber Products & 6.3 & -5.5 & 4.4 & -2.8 & 56.6 & 15.3 & 5.1 & 0.2 & 107.6 \\
\hline Chemical Products & 3.0 & 1.7 & 4.3 & 0.5 & 38.5 & 25.5 & 10.8 & 3.3 & 6.0 \\
\hline Iron and Steel & 0.4 & 0.6 & 7.5 & -2.7 & 4.3 & 6.9 & 4.4 & 0.7 & 4.7 \\
\hline Chemical Materials & 0.4 & 0.3 & 2.4 & 1.1 & 12.3 & 6.3 & -2.5 & -8.6 & 25.7 \\
\hline Petroleum and Coal & 0.2 & 0.8 & 2.4 & 0.8 & 5.8 & 9.5 & -21.1 & 10.7 & 28.7 \\
\hline
\end{tabular}


Table 4: Determinants of Change in the Gender Wage Gap, Taiwan (in log points $\times 100$; standard errors in parentheses)

\begin{tabular}{|c|c|c|c|c|}
\hline & (1) & (2) & (3) & (4) \\
\hline \multicolumn{5}{|c|}{ Panel A: Unadjusted Wage Gap } \\
\hline C & $\begin{array}{l}-15.23^{* * *} \\
(2.94)\end{array}$ & $\begin{array}{c}-54.13^{* * *} \\
(8.88)\end{array}$ & $\begin{array}{c}-18.35^{* * *} \\
(5.36)\end{array}$ & $\begin{array}{l}-69.28^{* * *} \\
(18.58)\end{array}$ \\
\hline$\Delta_{t} M_{t}$ & $\begin{array}{l}-4.73 \\
(3.43)\end{array}$ & $\begin{array}{c}28.12 \\
(22.05)\end{array}$ & $\begin{array}{l}-3.76^{*} \\
(2.07)\end{array}$ & $\begin{array}{l}61.72^{* * * *} \\
(18.68)\end{array}$ \\
\hline$C \times \Delta_{t} M_{t}$ & $\begin{array}{c}10.66^{*} \\
(5.08)\end{array}$ & $\begin{array}{c}43.37 \\
(32.76)\end{array}$ & $\begin{array}{l}17.83^{* * *} \\
(4.71)\end{array}$ & $\begin{array}{l}85.72^{* * * *} \\
(25.85)\end{array}$ \\
\hline constant & $\begin{array}{l}7.35^{* * *} \\
(1.89)\end{array}$ & $\begin{array}{l}-34.89^{* * *} \\
(5.68)\end{array}$ & $\begin{array}{l}12.02^{* * *} \\
(2.88)\end{array}$ & $\begin{array}{l}-42.34^{* * *} \\
(13.00)\end{array}$ \\
\hline$C$ & $\begin{array}{l}-9.51^{* *} \\
(3.61)\end{array}$ & $\begin{array}{l}-44.66^{* *} \\
(16.53)\end{array}$ & $\begin{array}{l}-4.18 \\
(4.62)\end{array}$ & $\begin{array}{l}-19.23 \\
(20.97)\end{array}$ \\
\hline$\Delta_{t} X_{t}$ & $\begin{array}{l}-1.79 \\
(1.61)\end{array}$ & $\begin{array}{c}2.20 \\
(10.37)\end{array}$ & $\begin{array}{c}4.26 \\
(5.24)\end{array}$ & $\begin{array}{l}-16.55 \\
(16.49)\end{array}$ \\
\hline$C \times \Delta_{t} X_{t}$ & $\begin{array}{l}-1.04 \\
(5.36)\end{array}$ & $\begin{array}{c}6.46 \\
(15.11)\end{array}$ & $\begin{array}{c}-4.22 \\
(11.33)\end{array}$ & $\begin{array}{c}-29.17 \\
(24.87)\end{array}$ \\
\hline constant & $\begin{array}{c}5.25 \\
(2.98)\end{array}$ & $\begin{array}{l}-28.40^{* *} \\
(9.71)\end{array}$ & $\begin{array}{c}7.80^{* *} \\
(2.74)\end{array}$ & $\begin{array}{c}-6.91 \\
(13.66)\end{array}$ \\
\hline \multicolumn{5}{|c|}{ Panel B: Residual Wage Gap } \\
\hline C & $\begin{array}{l}-6.86^{* *} \\
(3.00)\end{array}$ & $\begin{array}{l}-20.28^{* *} \\
(8.08)\end{array}$ & $\begin{array}{l}-11.03 \\
(6.96)\end{array}$ & $\begin{array}{l}-39.93 \\
(24.27)\end{array}$ \\
\hline$\Delta_{t} M_{t}$ & $\begin{array}{l}-1.17 \\
(1.86)\end{array}$ & $\begin{array}{c}37.28^{* *} \\
(13.10)\end{array}$ & $\begin{array}{l}-1.46 \\
(4.16)\end{array}$ & $\begin{array}{l}72.00^{* * *} \\
(17.71)\end{array}$ \\
\hline$C \times \Delta_{t} M_{t}$ & $\begin{array}{l}11.07^{* *} \\
(3.72)\end{array}$ & $\begin{array}{c}49.85^{* *} \\
(17.86)\end{array}$ & $\begin{array}{l}17.74^{* * *} \\
(5.57)\end{array}$ & $\begin{array}{l}96.21^{* * *} \\
(25.20)\end{array}$ \\
\hline constant & $\begin{array}{l}8.39^{* * * *} \\
(1.72)\end{array}$ & $\begin{array}{l}-8.31 \\
(5.91)\end{array}$ & $\begin{array}{l}12.62^{* *} \\
(5.47)\end{array}$ & $\begin{array}{l}-19.87 \\
(16.10)\end{array}$ \\
\hline$C$ & $\begin{array}{l}-2.01 \\
(3.71)\end{array}$ & $\begin{array}{c}-20.44 \\
(15.11)\end{array}$ & $\begin{array}{l}-0.66 \\
(6.51)\end{array}$ & $\begin{array}{c}4.99 \\
(31.11)\end{array}$ \\
\hline$\Delta_{t} X_{t}$ & $\begin{array}{l}-5.73 \\
(3.73)\end{array}$ & $\begin{array}{c}14.73 \\
(9.38)\end{array}$ & $\begin{array}{c}-4.29 \\
(10.29)\end{array}$ & $\begin{array}{c}-8.23 \\
(22.27)\end{array}$ \\
\hline$C \times \Delta_{t} X_{t}$ & $\begin{array}{c}8.64 \\
(6.04)\end{array}$ & $\begin{array}{c}25.90 \\
(15.01)\end{array}$ & $\begin{array}{c}9.11 \\
(14.47)\end{array}$ & $\begin{array}{l}-14.81 \\
(35.87)\end{array}$ \\
\hline constant & $\begin{array}{l}9.25^{* * *} \\
(2.53)\end{array}$ & $\begin{array}{l}-4.85 \\
(9.26)\end{array}$ & $\begin{array}{l}12.93^{* *} \\
(5.58)\end{array}$ & $\begin{array}{c}15.22 \\
(18.55)\end{array}$ \\
\hline
\end{tabular}

Note: Columns differ as follows: (1) $\mathrm{C}=$ dummy variable, estimation period is 1981-1999; (2) $\mathrm{C}=$ continuous variable, estimation period is 1981-1999; (3) C = dummy variable, estimation period is 19811996; and (4) $\mathrm{C}=$ continuous variable, estimation period is 1981-1996. The notation ${ }^{* * *}$ indicates statistically significant at the .01 level; ${ }^{* *}$ at the .05 level; ${ }^{*}$ at the .10 level. Each regression has 16 observations and is weighted using probability weights based on average-period employment levels by industry. The $\mathrm{R}^{2}$ statistics range from $33 \%$ to $52 \%$ for regressions with import ratios, and $1 \%$ to $32 \%$ for regressions with export ratios. 
Table 5: Determinants of Change in the Gender Wage Gap, Korea

(in $\log$ points $\times 100$; standard errors in parentheses)

\begin{tabular}{|c|c|c|c|c|}
\hline & (1) & (2) & (3) & (4) \\
\hline \multicolumn{5}{|c|}{ Panel A: Unadjusted Wage Gap } \\
\hline C & $\begin{array}{l}-10.83^{*} \\
(5.82)\end{array}$ & $\begin{array}{c}3.65 \\
(27.06)\end{array}$ & $\begin{array}{c}-4.60 \\
(5.81)\end{array}$ & $\begin{array}{c}5.48 \\
(19.53)\end{array}$ \\
\hline$\Delta_{t} M_{t}$ & $\begin{array}{l}-1.09 \\
(1.94)\end{array}$ & $\begin{array}{c}-5.14 \\
(15.91)\end{array}$ & $\begin{array}{c}-0.72 \\
(1.10)\end{array}$ & $\begin{array}{c}29.75 \\
(18.40)\end{array}$ \\
\hline$C \times \Delta_{t} M_{t}$ & $\begin{array}{l}-4.81 \\
(4.81)\end{array}$ & $\begin{array}{c}-6.66 \\
(26.62)\end{array}$ & $\begin{array}{c}8.68 \\
(10.82)\end{array}$ & $\begin{array}{c}46.71 \\
(28.73)\end{array}$ \\
\hline constant & $\begin{array}{l}-10.76^{* * *} \\
(3.24)\end{array}$ & $\begin{array}{l}-14.04 \\
(15.11)\end{array}$ & $\begin{array}{l}-13.95^{* * *} \\
(2.75)\end{array}$ & $\begin{array}{l}-13.93 \\
(10.60)\end{array}$ \\
\hline C & $\begin{array}{l}-16.21^{* *} \\
(7.67)\end{array}$ & $\begin{array}{c}-35.26 \\
(30.76)\end{array}$ & $\begin{array}{c}-8.06 \\
(4.74)\end{array}$ & $\begin{array}{c}-4.70 \\
(32.21)\end{array}$ \\
\hline$\Delta_{t} X_{t}$ & $\begin{array}{c}5.33^{* *} \\
(2.17)\end{array}$ & $\begin{array}{l}20.80^{* *} \\
(8.60)\end{array}$ & $\begin{array}{l}4.92^{* * * *} \\
(1.32)\end{array}$ & $\begin{array}{c}17.26^{*} \\
(9.66)\end{array}$ \\
\hline$C \times \Delta_{t} X_{t}$ & $\begin{array}{l}7.17 \\
(961)\end{array}$ & $\begin{array}{r}29.47^{*} \\
\end{array}$ & 7.68 & $\begin{array}{r}23.65^{*} \\
(1356\end{array}$ \\
\hline constant & $\begin{array}{l}-11.66^{* * *} \\
(2.42)\end{array}$ & $\begin{array}{l}-36.96^{*} \\
(17.81)\end{array}$ & $\begin{array}{l}-12.01^{* * *} \\
(1.45)\end{array}$ & $\begin{array}{l}-19.40 \\
(16.72)\end{array}$ \\
\hline \multicolumn{5}{|c|}{ Panel B: Residual Wage Gap } \\
\hline C & $\begin{array}{l}-10.66^{*} \\
(5.38)\end{array}$ & $\begin{array}{c}-10.99 \\
(18.38)\end{array}$ & $\begin{array}{l}-6.44 \\
(4.77)\end{array}$ & $\begin{array}{c}-11.13 \\
(14.71)\end{array}$ \\
\hline$\Delta_{t} M_{t}$ & $\begin{array}{c}1.86 \\
(2.80)\end{array}$ & $\begin{array}{c}5.82 \\
(9.60)\end{array}$ & $\begin{array}{c}0.61 \\
(2.41)\end{array}$ & $\begin{array}{l}25.92 \\
(9.86)\end{array}$ \\
\hline$C \times \Delta_{t} M_{t}$ & $\begin{array}{l}-1.36 \\
(3.80)\end{array}$ & $\begin{array}{c}6.36 \\
(15.94)\end{array}$ & $\begin{array}{c}8.20 \\
(5.87)\end{array}$ & $\begin{array}{c}38.88^{*} \\
(16.28)\end{array}$ \\
\hline constant & $\begin{array}{l}-1.40 \\
(4.57)\end{array}$ & $\begin{array}{l}-11.71 \\
(9.28)\end{array}$ & $\begin{array}{l}-2.43 \\
(4.16)\end{array}$ & $\begin{array}{l}-11.28^{*} \\
(6.30)\end{array}$ \\
\hline C & $\begin{array}{l}-15.96^{* * *} \\
(4.93)\end{array}$ & $\begin{array}{c}-37.39 \\
(22.41)\end{array}$ & $\begin{array}{l}-9.84^{* *} \\
(4.49)\end{array}$ & $\begin{array}{l}-21.63 \\
(22.00)\end{array}$ \\
\hline$\Delta_{\iota} X_{t}$ & $\begin{array}{c}1.21 \\
(5.25)\end{array}$ & $\begin{array}{l}14.06^{* * *} \\
(3.60)\end{array}$ & $\begin{array}{c}3.60 \\
(3.48)\end{array}$ & $\begin{array}{l}11.25^{*} \\
(4.20)\end{array}$ \\
\hline$C \times \Delta_{t} X_{t}$ & $\begin{array}{c}7.05 \\
(6.34)\end{array}$ & $\begin{array}{c}21.46^{*} \\
(10.45)\end{array}$ & $\begin{array}{c}3.57 \\
(4.78)\end{array}$ & $\begin{array}{r}13.27 \\
(8.07)\end{array}$ \\
\hline constant & $\begin{array}{l}-0.78 \\
(3.88)\end{array}$ & $\begin{array}{l}-26.87^{* *} \\
(11.45)\end{array}$ & $\begin{array}{l}-0.33 \\
(3.58)\end{array}$ & $\begin{array}{l}-16.06 \\
(10.16)\end{array}$ \\
\hline
\end{tabular}

Note: Columns differ as follows: (1) $\mathrm{C}=$ dummy variable, estimation period is 1980-1998; (2) $\mathrm{C}=$ continuous variable, estimation period is 1980-1998; (3) C = dummy variable, estimation period is 19801996; and (4) $\mathrm{C}=$ continuous variable, estimation period is $1980-1996$. The notation ${ }^{* * *}$ indicates statistically significant at the .01 level; ${ }^{* *}$ at the .05 level; ${ }^{*}$ at the .10 level. Each regression has 23 observations and is weighted using probability weights based on average-period employment levels by industry. The $\mathrm{R}^{2}$ statistics range from $1 \%$ to $27 \%$ for regressions with import ratios, and $18 \%$ to $34 \%$ for regressions with export ratios. 
Figure 1: Manufacturing-Sector Female/Male Wage Ratios: Cross-Country Evidence

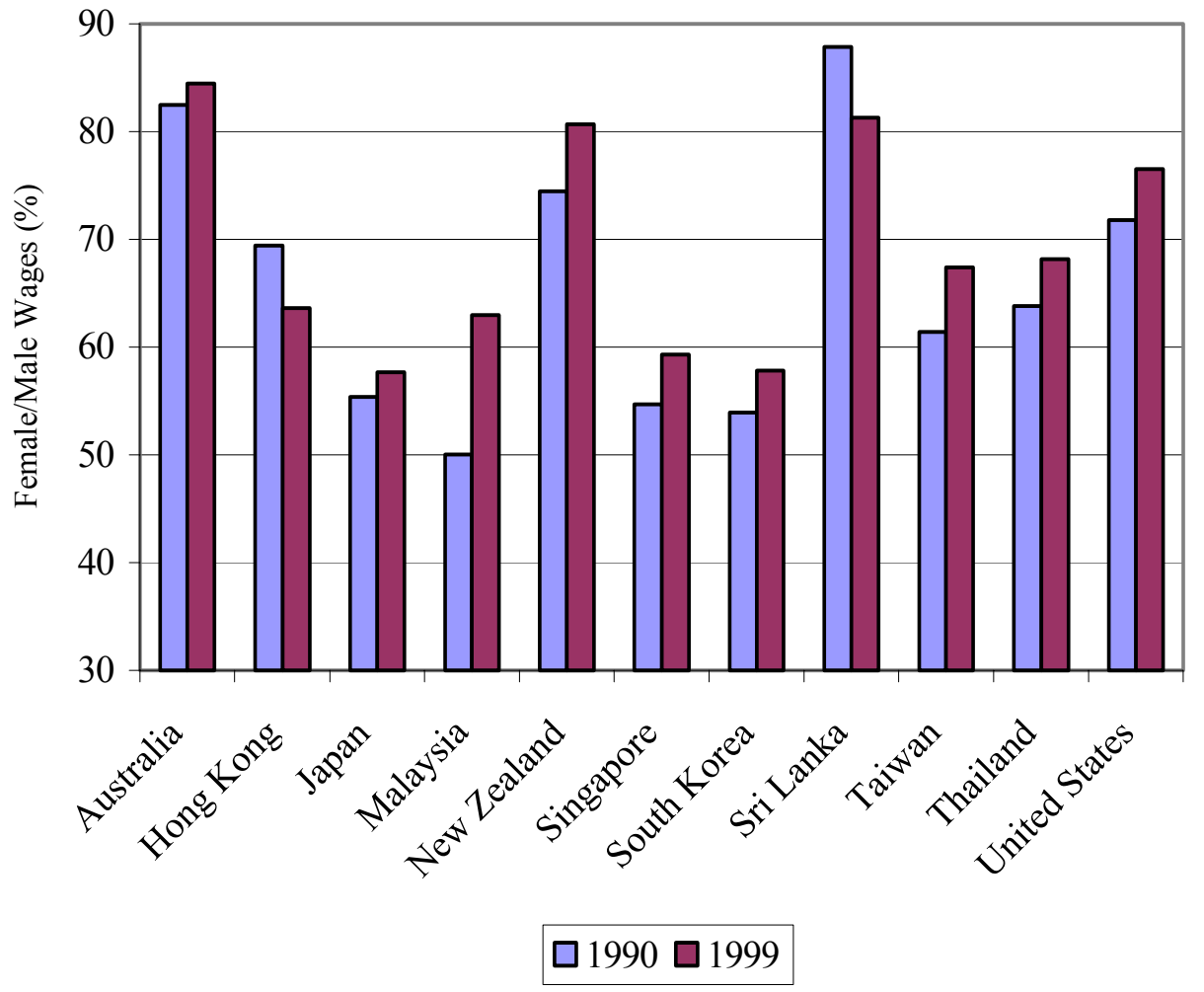

Note: Wage data are for 1990 and 1999, or for the closest available years.

Sources: International Labour Office (2000); authors' calculations for South Korea and Taiwan. 
Figure 2: Gender Wage Ratios by Manufacturing Industry Status, Taiwan and Korea

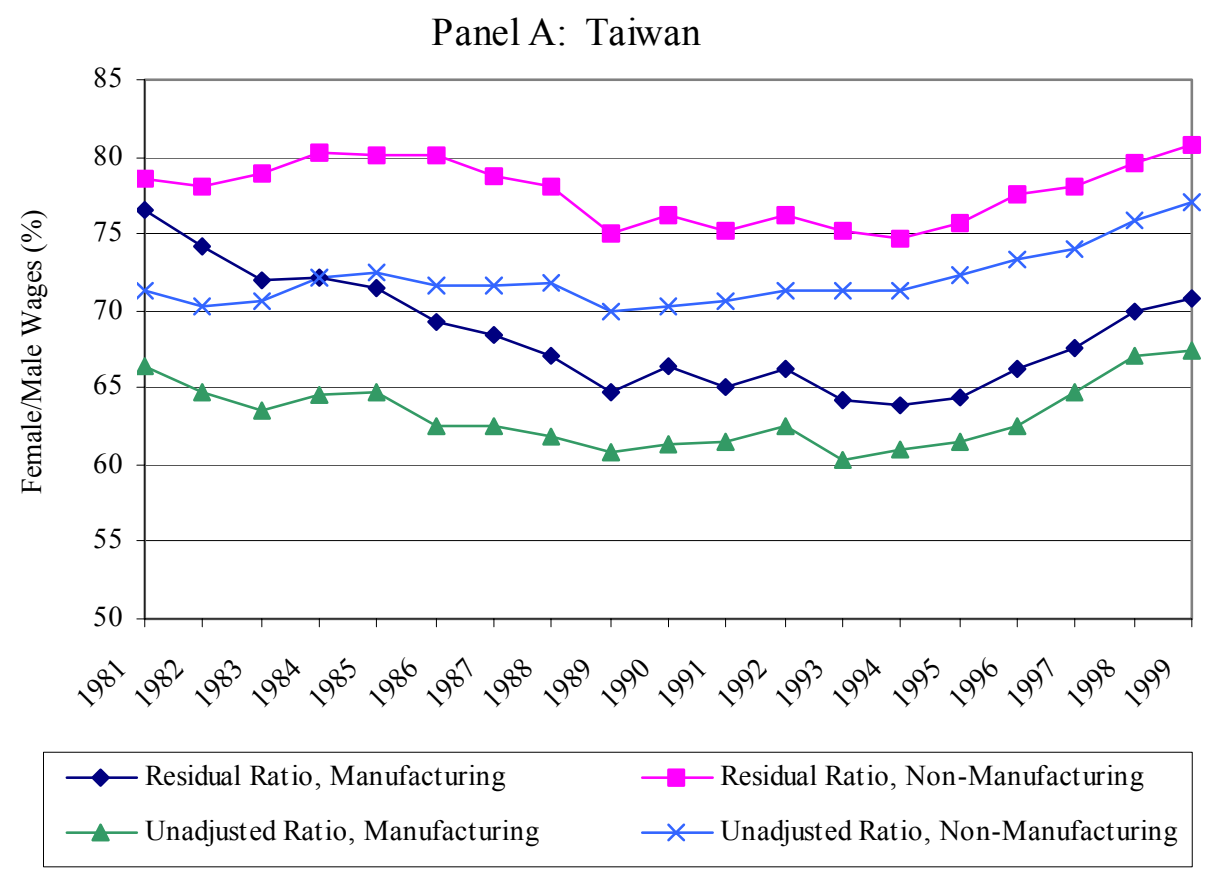

Panel B: Korea

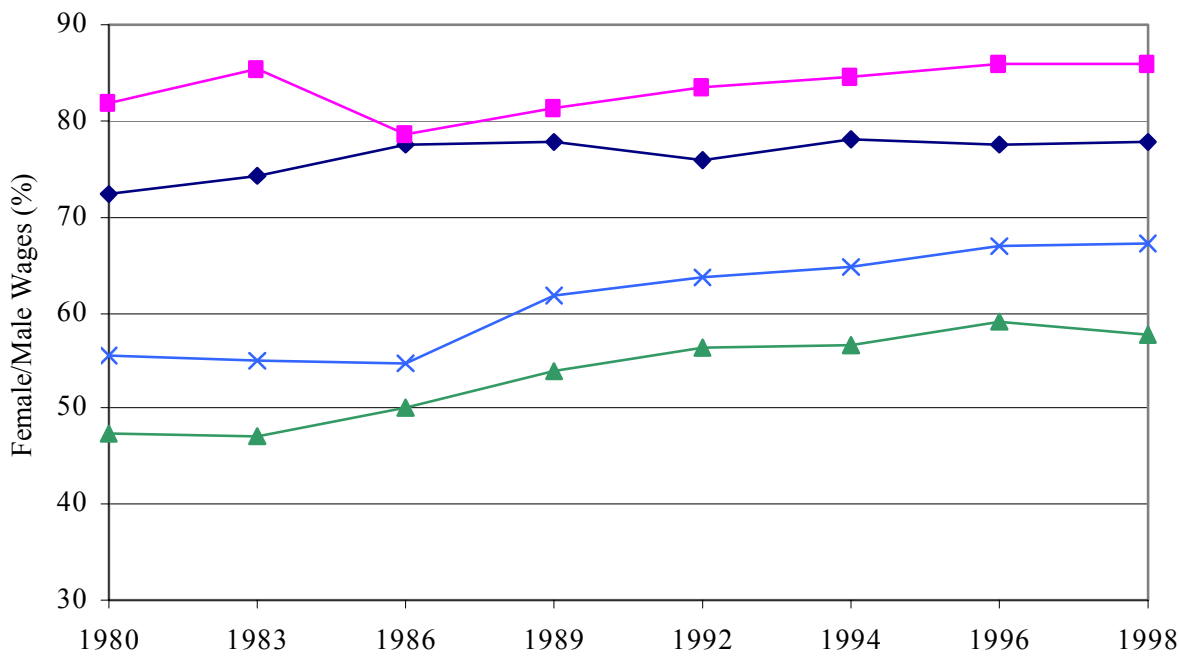

$\begin{array}{ll}- \text { Residual Ratio, Manufacturing } & - \text { Residual Ratio, Non-Manufacturing } \\ - \text { Unadjusted Ratio, Manufacturing } & - \text { Unadjusted Ratio, Non-Manufacturing }\end{array}$ 
Figure 3: Gender Wage Ratios and Manufacturing Trade Ratios, Taiwan and Korea

Panel A: Taiwan

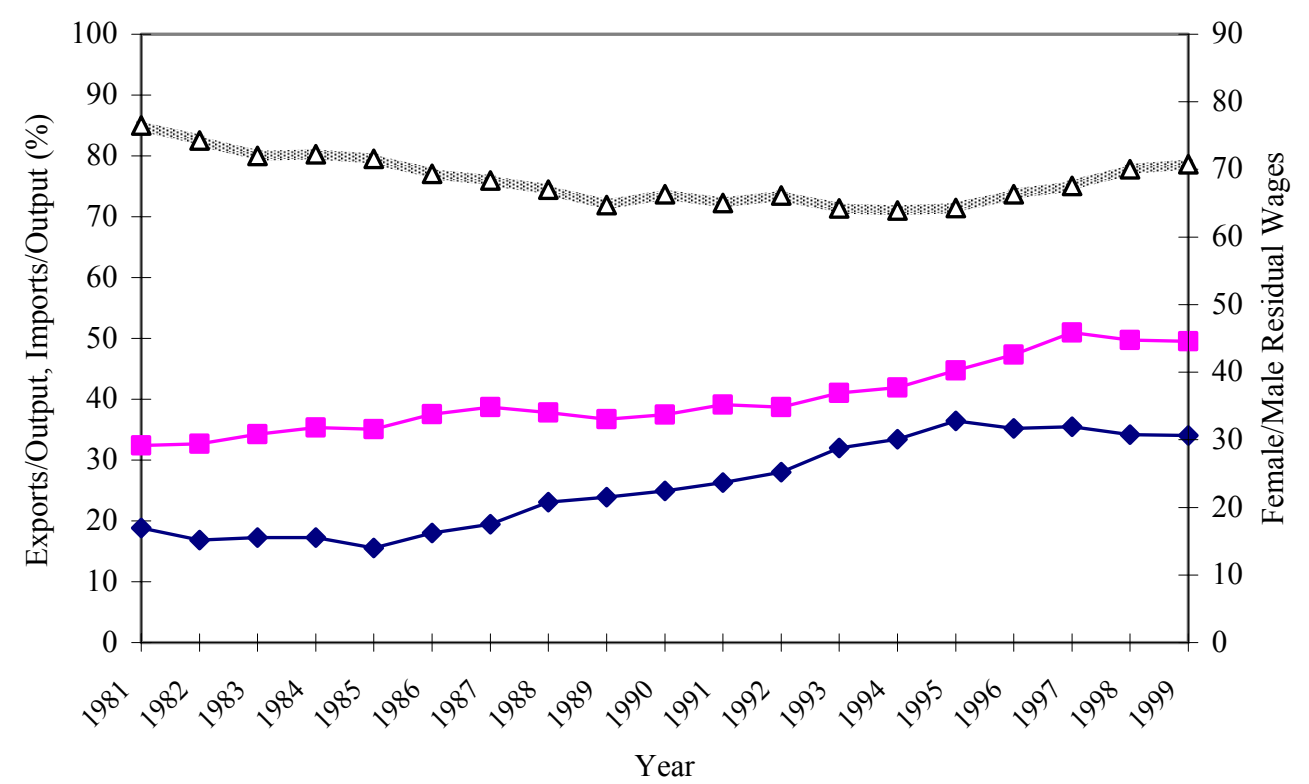

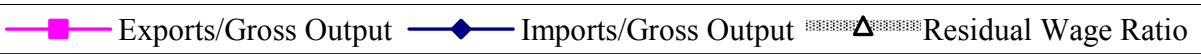

Panel B: Korea

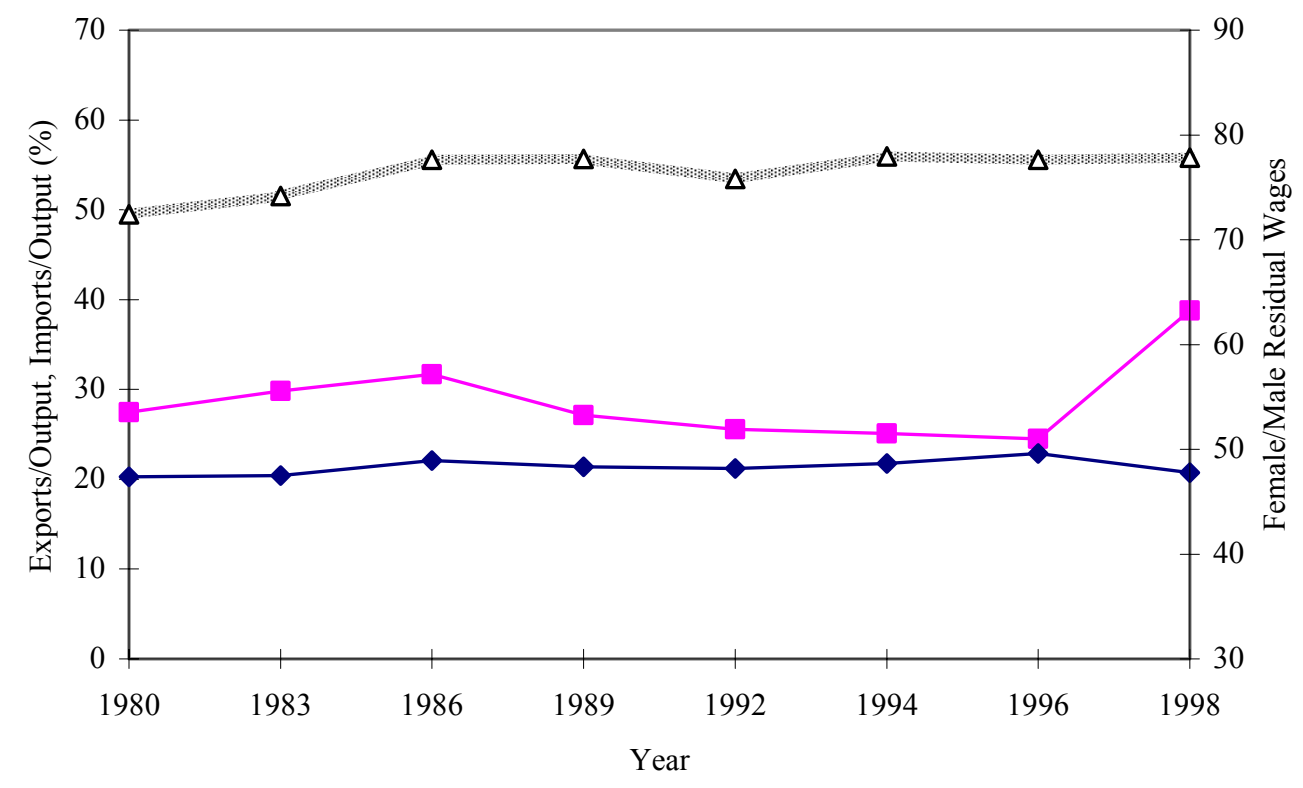


Figure 4: Gender Wage Ratios by Industry Concentration, Taiwan and Korea

Panel A: Gender Wage Ratios, Taiwan

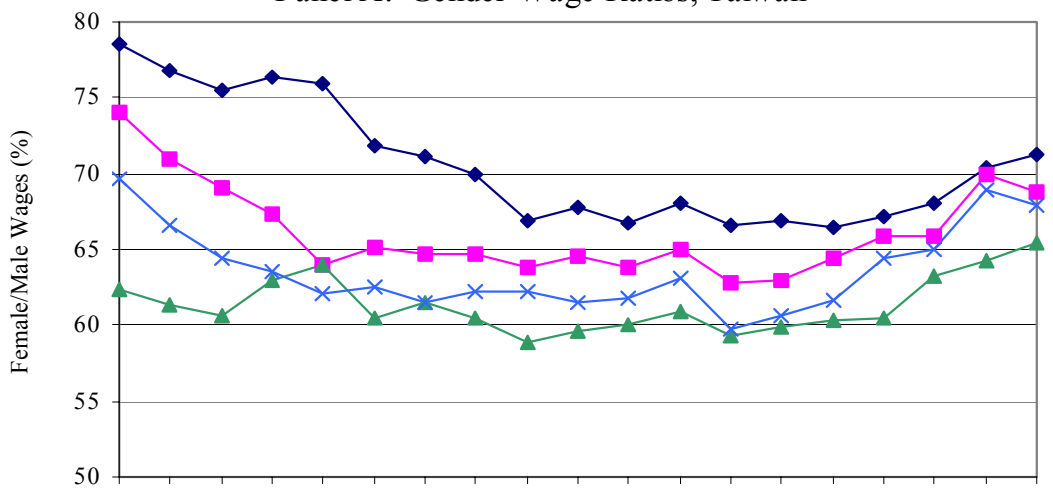

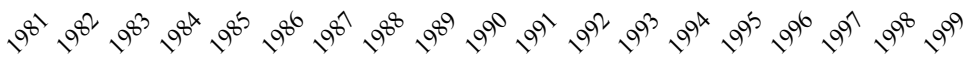

$\longrightarrow$ Residual Ratio, Concentrated
$\longrightarrow$ Unadjusted Ratio, Concentrated
$-\leftarrow$ Unadjusted Ratio, Non-Concentrated

Panel C: Gender Wage Ratios, Korea

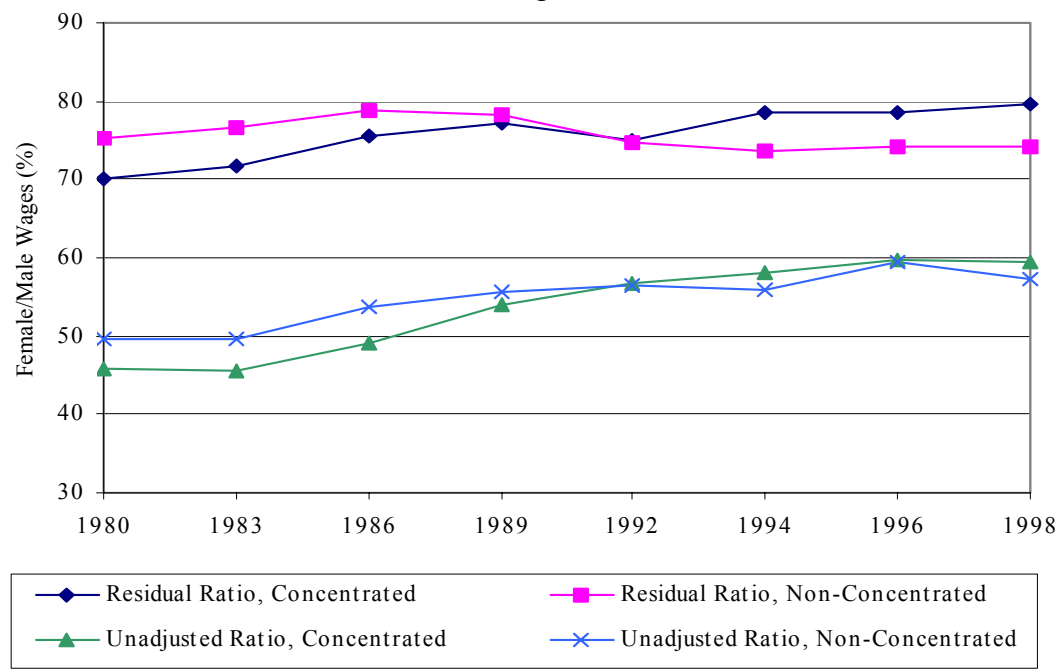

Panel B: Male and Female Wage Levels, Taiwan
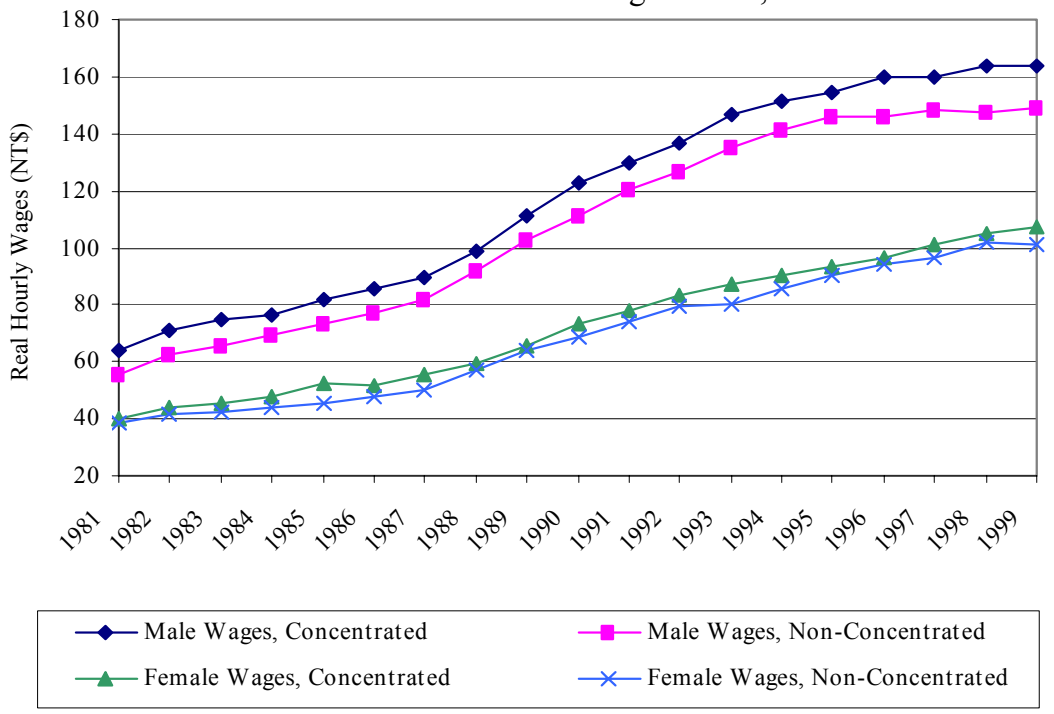

Panel D: Male and Female Wage Levels, Korea

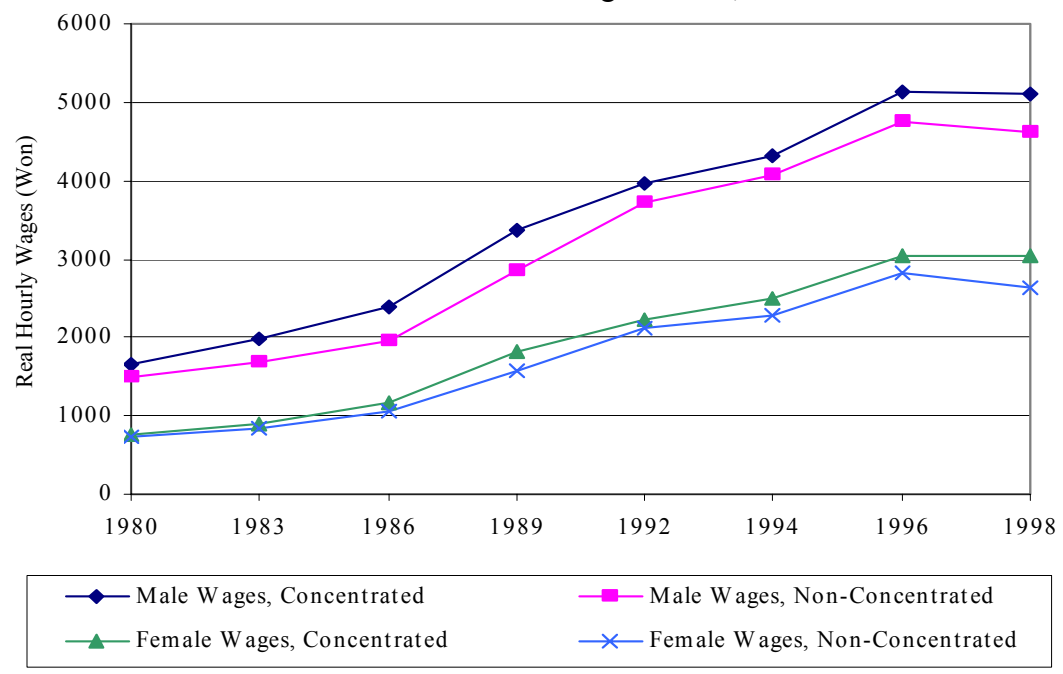

39 


\section{References}

Amsden, Alice H. and Wan-Wen Chu. 2002. Upscaling: Recasting Old Theories to Suit Late Industrializers. In Peter C. Y. Chow, eds., Taiwan in the Global Economy: From an Agrarian Economy to an Exporter of High-Tech Products, Westport, CT: Praeger.

Amsden, Alice. 2001. The Rise of "The Rest": Challenges to the West From LateIndustrializing Economies. Oxford: Oxford University Press.

Artecona, Raquel, and Wendy Cunningham. 2001. Effects of Trade Liberalization on the Gender Wage Gap in Mexico. World Bank, Background Paper to the Policy Research Report on Gender and Development.

Australia National University (ANU). 2001. International Economic Data Bank: ISIC International Trade Data. Australia: ANU.

Becker, Gary. 1959. The Economics of Discrimination. Chicago, IL: University of Chicago Press.

Behrman, Jere, and Elizabeth King. 1999. Competition and Gender Gaps in Wages: Evidence from 16 Countries. World Bank, Background Paper to the Policy Research Report on Gender and Development.

Berik, Günseli. 2000. Mature Export-led Growth and Gender Wage Inequality in Taiwan. Feminist Economics 6 (3): 1-26.

Black, Sandra, and Elizabeth Brainerd. 2000. Importing Equality? The Impact of Globalization on Gender Discrimination. Federal Reserve Bank of New York Working Paper.

Black, Sandra, and Philip Strahan. 2001. The Division of Spoils: Rent-Sharing and Discrimination in a Regulated Industry. American Economic Review 91 (4): 814-831. 
Borjas, George, and Valerie Ramey. 1995. Foreign Competition, Market Power, and Wage Inequality. Quarterly Journal of Economics 110 (4): 1075-1110.

Central Bank of China (CBC). Various years. Financial Statistics (IMF). Taipei: CBC.

Chen, Fen-ling. 2001. Working Women and State Policies in Taiwan. New York, NY: Palgrave.

Chen, Tain-Jy and Yi-Ping Chen. 1995. Foreign Direct Investment and Deindustrialization: The Case of Taiwan. Journal of Industry Studies 2 (1): 57-68.

Cheng, Lucie, and Ping-Chun Hsiung. 1994. Women, Export-Oriented Growth, and the State: The Case of Taiwan. In Joel Aberbach, David Dollar, and Kenneth Sokoloff (eds.), The Role of the State in Taiwan's Development. Armonk, NY: M.E. Sharpe.

Chiu, Su-fen. Politics of Protective Labor Policy-Making: A Case Study of the Labor Standards Law in Taiwan. Ph.D. dissertation. Madison, WI: University of Wisconsin-Madison, 1993.

Curry, B. and K.D. George. 1983. Industrial Concentration: A Survey. Journal of Industrial Economics 31 (3): 203-255.

Darity, William. 1989. What's Left of the Economic Theory of Discrimination? In Steve Shulman and William Darity (eds.), The Question of Discrimination. Middletown: Wesleyan University Press.

Directorate-General of Budget, Accounting, and Statistics, Executive Yuan (DGBAS). 1987. Standard Industrial Classification of the Republic of China, Revision 4, Taipei: DGBAS. - 1991. Standard Industrial Classification of the Republic of China, Revision 5, In Chinese, Taipei: DGBAS. . Various years. Monthly Bulletin of Statistics. Taipei: DGBAS. 
Gladwin, Christina, and Carrie Thompson. 1995. Impacts of Mexico's Trade Openness on Mexican Rural Women. American Journal of Agricultural Economics 77 (3): 712-718.

Hartmann, Heidi. 1976. Capitalism, Patriarchy, and Job Segregation by Sex. Signs: Journal of Women in Culture and Society 1 (2): 137-169.

Hellerstein, Judith, David Neumark, and Kenneth Troske. 1997. Market Forces and Sex Discrimination. National Bureau of Economic Research, Working Paper No. 6321.

International Labour Office (ILO). 2000. Yearbook of Labour Statistics. Geneva: ILO.

Kang, Myung Soo. 2001. A Study on Changes of Wage Distribution in Korea, 1976-1998, From the Perspective of Skill-Biased Technological Changes. Dissertation. Columbia, Missouri: University of Missouri-Columbia.

Levinsohn, James. 1993. Testing the Imports-As-Market-Discipline Hypothesis. Journal of International Economics 35: 1-22.

Mason, Patrick. 1999. Male Interracial Wage Differentials: Competing Explanations. Cambridge Journal of Economics 23: 261-299.

Mason, Patrick, and Rhonda Williams. 1997. The Janus Face of Race: Reflections on Economic Theory. In Patrick Mason and Rhonda Williams (eds.), Race, Markets, and Social Outcomes. Boston/Dordrecht/London: Kluwer Academic Publishers.

Meng, Xin. 1996. The Economic Position of Women in Asia. Asian-Pacific Economic Literature 10 (1): 23-41.

Milkman, Ruth. 1990. Gender and Trade Unionism in Historical Perspective. In Louise Tilly and Patricia Gurin (eds.), Women, Politics, and Change. New York: Russell Sage Foundation. 
Nam, Jeong-Lim. 1994. Women's Role in Export Dependence and State Control of Labor Unions in South Korea. Women's Studies International Forum 17 (1): 57-67.

National Statistical Office, Republic of Korea (NSO). 2001. Korean Standard Industrial Classification Revision 7, Seoul: NSO.

Oaxaca, Ronald. 1973. Male-Female Wage Differentials in Urban Labor Markets. International Economic Review 14 (3): 693-709.

Rodgers, Yana. 1998. A Reversal of Fortune for Korean Women: Explaining the 1983 Upward Turn in Relative Earnings. Economic Development and Cultural Change 46 (4): 727-748.

Seguino, Stephanie. 1997. Gender Wage Inequality and Export-Led Growth in South Korea. Journal of Development Studies 34 (2): 102-132.

. 2000. The Effects of Structural Change and Economic Liberalisation on Gender Wage Differentials in South Korea and Taiwan. Cambridge Journal of Economics 24: 437-459.

Stiglitz, Joseph, and Shahid Yusuf (eds.). 2001. Rethinking the East Asian Miracle. Oxford: Oxford University Press.

United Nations Industrial Development Organization (UNIDO). 2000. Industrial Statistics (ISIC 3-digit level) Database. CD-ROM. Vienna, Austria: UNIDO.

Williams, Rhonda M. and Robert E. Kenison. 1996. The Way We Were?: Discrimination, Competition, and Inter-Industry Wage Differentials in 1970. Review of Radical Political Economics 28 (2): 1-32.

Winter-Ebmer, Rudolf. 1995. Sex Discrimination and Competition in Product and Labour Markets. Applied Economics 27 (9): 849-857. 
World Bank. 2001. Engendering Development: Through Gender Equality in Rights, Resources, and Voice. Oxford: Oxford University Press.

Zveglich, Joseph, Yana Rodgers, and William Rodgers. 1997. The Persistence of Gender Earnings Inequality in Taiwan, 1978-1992. Industrial and Labor Relations Review 50 (4): 594-609.

Zveglich, Joseph, and Yana Rodgers. 2002. Occupational Segregation and the Gender Wage Gap in a Dynamic East Asian Economy. Manuscript. 


\section{Endnotes}

${ }^{1}$ Korea's total trade ratio fell continuously from a high of $56 \%$ in 1985 to a low of $45 \%$ in 1993 , thereafter rising again, owing to the collapse of output, to $51 \%$ in 1997 and $60 \%$ in 1998 .

${ }^{2}$ Becker's original notion of competitiveness is based on characteristics of domestic industrial structure. More recent empirical studies on discrimination include international trade as a potential source of increased competitiveness. Behrman and King (1999) report that the idea that international trade increases competition or imposes market discipline is a longstanding one in the trade literature, and one that has recently found empirical support in Levinsohn (1993).

${ }^{3}$ A common technique, based on Oaxaca (1973), uses cross-sectional data on workers and decomposes the wage gap in individual years into a portion explained by measured skill differences between men and women, and a residual portion commonly attributed to wage discrimination.

4 The World Bank (2001) further discusses the mixed evidence on increased labor market competition and the gender wage gap.

5 The summary of theoretical frameworks is based on Darity (1989), Williams and Kenison (1996), Mason and Williams (1997), and Mason (1999).

${ }^{6}$ This approach is followed because the Taiwan survey reports monthly earnings and weekly hours worked.

${ }^{7}$ In particular, the regressions for both Taiwan and Korea include a dummy variable for parttime worker (less than forty hours per week for Taiwan or 160 hours per month for Korea), dummy variables for education level attained, years of potential experience (age, minus education, minus six) and its square, years of establishment-specific tenure and its square, and dummy variables for regional locations. In addition, regressions for Taiwan include dummy 
variables for major area of study and a dummy variable for urban status, while regressions for Korea include dummy variables for occupation-specific experience.

${ }^{8}$ The implicit assumption is that male coefficients more accurately reflect competitive returns to observable characteristics than female coefficients. An alternative approach combines coefficient estimates for both men and women following Oaxaca (1973). These two approaches yield the same measures for the total, predicted, and residual earnings gaps.

${ }^{9}$ The data source presents size categories as ranges. In the estimations, size levels are chosen to be the mid-point for each range. Because the final range has no upper bound, the size level is top coded as 1.2 times the lower bound.

${ }^{10}$ In further robustness checks, results are compared with rankings based on available data for number of enterprise (or establishment) units divided by output per industry, the K-firm concentration ratio, the Herfindahl index, and the profit rate by industry.

11 See Amsden (2001) and Stiglitz and Yusuf (2001) for discussions of the competitive environment within the export and import-competing sectors. Also, data constraints for measures related to trade policy in both Taiwan and Korea limit our options for measuring international competitiveness.

12 For each country, the residual wage ratio in manufacturing and non-manufacturing industries is calculated using a wage regression based on the full set of non-farm employees.

13 For Taiwan, observed productivity characteristics explain about $40 \%$ to $60 \%$ of the gender wage differential during the 1980s and early 1990s (Zveglich, Rodgers, and Rodgers 1997), while for Korea, observed characteristics explain about $70 \%$ to $80 \%$ of the gender wage differential during the same period (Rodgers 1998). 
14 The aggregate manufactured export share is constructed as total manufactured exports divided by total manufactured output, and similarly for imports.

15 The sharp rise in the aggregate export ratio between 1996 and 1998 reflects the dramatic drop in output due to the Asian crisis.

16 This inverse relationship between industry competitiveness and wage levels holds at the interindustry level in a given year as well, especially in the early 1980s, and is robust to the measure of industry concentration used.

17 Similar to Taiwan, in a given year, the more concentrated the industry the higher the wages of both men and women, and this relationship is also robust to the measure of industry concentration used.

${ }^{18}$ Chen and Chen (1995) indicate that in Taiwan, outward foreign direct investment in textiles and apparel is largely motivated by attempts to maintain firm competitiveness by relocation to lower wage sites. The relocation of apparel to China and South East Asia stimulated expansion of exports of selected products in textiles to these countries, fostering cross-border linkage effects based on prior vertical integration of these industries in Taiwan. However, this linkage has not prevented the decline of textiles in Taiwan given the loss of European and U.S. export markets and the simultaneous undermining of cross border linkages by some textile firms that invested abroad along with apparel factories. This intra-industry restructuring is consistent with a gendered restructuring of employment opportunities, whereby men's employment expands in the growing, higher-paying subsectors of textiles, while women's job opportunities decline or are reclassified as the lower tier jobs in textiles and apparel.

19 It is possible that electronics, which is undergoing technological upscaling, now meets domestic demand and exports less of its output to the world market. 
${ }^{20}$ The minimum cell size for a gender-industry group in the sample period was 13 . Larger cell sizes would entail a tradeoff with degrees of freedom in the model estimations. 